See discussions, stats, and author profiles for this publication at: https://www.researchgate.net/publication/337185667

\title{
Mitigating crop yield losses through weed diversity
}

Article $\cdot$ November 2019

DOI: 10.1038/541893-019-0415-y

CITATIONS

0

6 authors, including:

Guillaume Adeux

1.) French National Institute for Agricultural Research

11 PUBlications 4 Citations

SEE PROFILE

\section{READ}

37

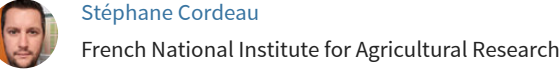

73 PUBLICATIONS 307 CITATIONS

SEE PROFILE

Some of the authors of this publication are also working on these related projects:

VANCOUVER : Valorisation des couverts végétaux dans les systèmes de culture pour la gestion agroécologique de la flore adventice View project

ANR-17-CE32-0011 Next Generation Biomonitoring (NGB) of change in ecosystem structure and function View project 


\title{
Mitigating crop yield losses through weed diversity
}

\author{
Guillaume Adeux ${ }^{1,2}$, Eric Vieren', Stefano Carlesi ${ }^{1}{ }^{2}$, Paolo Bàrberi², Nicolas Munier-Jolain' and \\ Stéphane Cordeau ${ }^{1 *}$
}

Reconciling crop productivity and biodiversity maintenance is one of the main challenges of agriculture worldwide. Moreover, the importance of weed diversity in mitigating yield losses has been identified as one of the top five research priorities in weed science. We tested the hypotheses that (1) not all weed communities generate yield losses and (2) that more diversified weed communities can mitigate yield losses. The study is based on three years of observations of weed densities, weed biomass and crop biomass at four critical growth stages of winter cereals across 54 zones (36 unweeded and 18 weeded). Out of the six communities identified, only four generated significant yield losses in unweeded zones, ranging from $19 \%$ to $56 \%$. The number of ears per plant and the number of grains per ear were systematically affected. Only one weed community was capable of reducing 1,000-kernel weight. Weed biomass decreased by $83 \%$ over the gradient of weed community evenness, whereas crop productivity increased by $23 \%$. Diversified weed communities limited the negative effect of competitive and dominant species on crop productivity while potentially promoting ecosystem services provided by subordinate species.

W eeds can represent a major constraint to crop produc tion $^{1,2}$. Herbicides have proven to be an effective weed management tool. However, the oversimplification of cropping systems in combination with herbicide use has led to the evolution of weed resistance and loss of weed diversity, reflected by the emergence of a few dominant and competitive weed species ${ }^{3-5}$, such as Galium aparine L. ${ }^{6}$ and Alopecurus myosuroides Huds. ${ }^{7}$. Another consequence is that this loss of biodiversity in agricultural landscapes has eroded the agroecosystem services provided by weeds, which are essential to sustainable crop production ${ }^{8,9}$. These two seemingly opposite visions, that is, the vision of the detrimental versus the beneficial aspects of weeds, could be reconciled by recognizing that maintaining weed diversity and preventing the dominance of a few competitive weed species rely on the same set of ecological and management principles ${ }^{5}$. In fact, the importance of weed diversity in mitigating yield losses has been identified as one of the top five research priorities in current weed science ${ }^{10}$.

Weed-crop interference has been studied mainly through experimental designs that considered only one weed species at a time ${ }^{11}$. Hence, little is known about the competitive effect of weeds in complex communities ${ }^{12}$ or how weed diversity might affect crop productivity ${ }^{13}$. More diverse weed communities should exhibit more weed-weed interference ${ }^{14}$. Indeed, when tested in multi-species assemblages, authors have highlighted non-additive effects. These results suggest that the assumption of additive competitive effect in multi-species assemblages overestimates the competitive effect of weed communities ${ }^{12}$. Non-additive effects can be explained by indirect interactions (for example, 'an enemy of an enemy is a friend of mine' or 'rock-paper-scissors' ${ }^{15,16}$ ) or increased asymmetric and interspecific competition within the weed community ${ }^{12,14,17-19}$. However, artificially assembled weed communities can be confounded by a sampling effect and often reveal non-additive interactions for specific combinations of species ${ }^{12}$. Therefore, so far, there is little scientific support for the importance of non-additive interactions in real weed communities that were shaped by a coherent set of agronomic practices (that is, naturally assembled weed communities), rather than experimental conditions (for example, an abandoned field ${ }^{20}$, a long-term wheat monoculture fertilization experiment ${ }^{5}$ or an experimental neighbourhood approach with four weed species ${ }^{12}$ ).

Approaches based on ecological traits have allowed a shift in perspective from taxonomy to function ${ }^{21}$ and have yielded successful predictions of competitive outcomes ${ }^{22,23}$. Indeed, the taxonomy-based indicators used in previous studies s, $12,13,20,24-26$ lacked the ability to reflect the functional structure of the weed community, which governs competition processes. Competitive weed communities express traits related to rapid acquisition of resources (that is, high seed mass, high canopy height, high specific leaf area, high leaf nitrogen content and same phenology as the crop ${ }^{22,23,27}$, and their competitive effect on the crop is exacerbated by increasing density ${ }^{28}$.

According to ecological-niche-based theory, weed-crop interference is most intense when the weed community occupies the same niche as the $\operatorname{crop}^{29,30}$. Hence, a high functional diversity within the weed community should induce complementarity in resource use in space and time (that is, niche complementarity), resulting in a reduced probability of intense niche overlap with the crop and crop yield loss due to dominant and competitive weed ${ }^{21}$. However, higher functional differentiation between the crop and the weed community can also lead to competitive hierarchies ${ }^{31}$, the scenario under which the competitive outcome will be determined by whom possesses the most advantageous value of a specific trait and, hence, the species forming the community. Moreover, crop yield components (such as number of ears per plant, number of grains per ear and 1,000-kernel weight) are determined at distinct stages of crop development and could provide additional insight on how weed community functional structure relates to weed-crop interference in time ${ }^{32}$.

The objective of this study was to identify naturally assembled weed communities and weed community features (based on either taxonomy or traits, using density or biomass data) that do not

${ }^{1}$ Agroécologie, AgroSup Dijon, INRA, Univ. Bourgogne, Univ. Franche-Comté, Dijon, France. ²Group of Agroecology, Institute of Life Sciences, Scuola Superiore Sant'Anna, Pisa, Italy. *e-mail: stephane.cordeau@inra.fr 
jeopardize crop productivity. More specifically, we asked, are all weed communities detrimental to crop productivity? Can weed diversity mitigate yield losses? We hypothesized that not all weed communities are detrimental to crop productivity, because the species forming the weed community can have lower competitive trait values than the crop species. Moreover, the crop may have the ability to compensate for yield components affected early in the season through yield components elaborated later in the season. We also hypothesized that, from a taxonomic point of view, more diversified weed communities reduce the dominance of competitive species, resulting in less weed biomass and less interference with the crop. Finally, we hypothesized that, from a functional point of view, more diversified weed communities increase the probability of niche overlap with the crop but reduce its intensity because of lower saturation of weed community trait space. This study is based on three years of observations of weed densities, weed biomass and crop biomass at four critical growth stages of winter cereals across 54 zones (weeded or unweeded).

\section{Results}

During the initial winter scoutings, 28 species were recorded across the 216 weedy quadrats. Initial weed density ranged from 4 to 470 plants $\mathrm{m}^{-2}(\bar{x}=100)$, species richness from 1 to 10 species per quadrat $(\bar{x}=3.8)$, Shannon diversity index from 0 to $1.7(\bar{x}=0.8)$, evenness from 0 to $1(\bar{x}=0.6)$ and Rao's quadratic index from 0 to $7.2(\bar{x}=2.4)$. Alopecurus myosuroides (ALOMY), Veronica hederifolia (VERHE), Galium aparine (GALAP), Viola arvensis (VIOAR), Stellaria media (STEME), Geranium dissectum (GERDI) and Veronica persica (VERPE), all common weed species associated with winter cereals in France, represented 39\%, $18 \%, 14 \%, 13 \%, 5 \%, 5 \%$ and $4 \%$, respectively, of the total initial weed density. Sixteen additional species were recorded during the following four biomass samplings. At stem elongation, ALOMY, VERHE, GALAP and STEME represented 55\%, 19\%, 15\% and 7\%, respectively, of the total sampled biomass. At heading, ALOMY, GALAP, VERHE and STEME represented $65 \%, 21 \%, 6 \%$ and $3 \%$, respectively, of the total sampled biomass. At filling and maturity, sampled biomass was dominated by ALOMY (57-58\%) and GALAP (33-34\%).

Quantification of yield losses across all weed communities. When weed communities were not considered, yield varied according to crop density, management type, hand weeding and management type $\times$ hand weeding (coefficient of determination $\left(R^{2}\right)$ for fixed effects $=0.68$; Supplementary Table 1 for analysis of variance table). In unweeded, or 'no weed control' (NWC), zones, grain yields (expressed in terms of dry matter (DM)) were significantly reduced by $30 \%\left(-167 \mathrm{~g} \mathrm{DM} \mathrm{m}^{-2}\right.$, that is $-1.97 \mathrm{tha}^{-1}$ at $15 \%$ standard humidity) in weedy quadrats (Supplementary Fig. 1) in comparison with weed-free quadrats (pre-planned contrast on log scale $=\mathrm{NWC}_{\text {Weed-free }}-\mathrm{NWC}_{\text {Weedy, }}$ estimate $=0.36$, s.e.m. $=0.053$, d.f. $=53.71, t$-ratio $=6.67, P<0.0001)$. In weeded, or 'standard weed control' (SWC), zones, grain yields did not significantly differ between weedy and weed-free quadrats (pre-planned contrast on $\log$ scale $=\mathrm{SWC}_{\text {Weed-free }}-\mathrm{SWC}_{\text {Weedy }}$ estimate $=-0.02$, s.e.m. $=0.073$, d.f. $=53.86, t$-ratio $=-0.315, P=0.75)($ Supplementary Fig. 1$)$.

Identification of weed communities that minimize yield loss. Description of weed communities. The zones captured $84 \%$ of weed community variability between quadrats. Hence, zones were classified into six contrasting weed community clusters (WCCs, denoted C1 to C6 hereafter; Supplementary Fig. 2). Weed density was lowest in $\mathrm{C} 1$ and $\mathrm{C} 4$, intermediate in $\mathrm{C} 3, \mathrm{C} 5$ and $\mathrm{C} 6$, and highest in C2 (Table 1 for least squares means, Fig. 1 for observed means and composition and Supplementary Table 2 for analysis of variance tables). All six WCCs presented similar species richness (Table 1

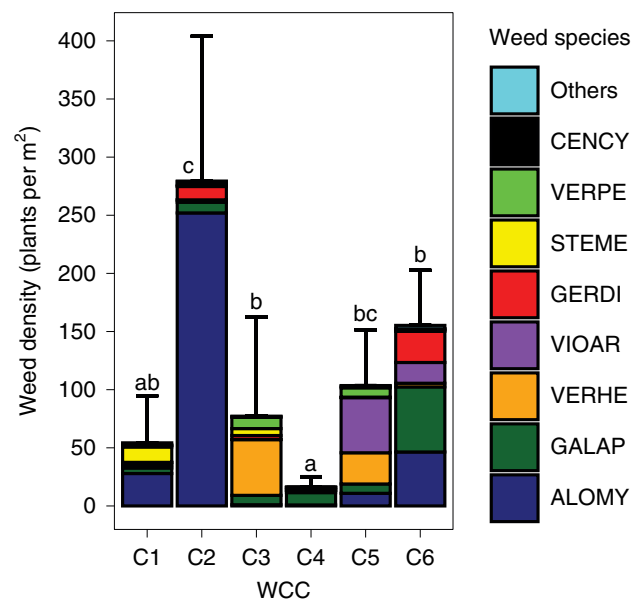

Fig. 1 | Observed mean weed density and composition in the six WCCs (denoted C1 to C6) obtained by hierarchical classification. Error bars represent \pm 1 s.d. around mean total weed density. Bars sharing the same letter show no significant differences in terms of total weed density at $P<0.05$. Only the eight most abundant species are represented for graphical purposes (ALOMY, VERHE, GALAP, VIOAR, GERDI, STEME, VERPE and Cyanus segetum (CENCY)).

and Supplementary Table 2). Compared with C2, all other WCCs presented greater values of Shannon diversity index, evenness and Rao's quadratic entropy (Table 1). However, communities differed in terms of community composition. C1 was mainly composed of ALOMY (51\%) and STEME (24\%) (Fig. 1). C2 was dominated by ALOMY (90\% of total weed density, Fig. 1). C3 was mainly composed of VERHE (62\%), whereas C4 was mainly composed of GALAP (66\%) (Fig. 1). C5 was mainly composed of VIOAR (46\%) and VERHE (26\%), whereas C6 was mainly composed of GALAP (36\%) and ALOMY (30\%) (Fig. 1).

These differences in weed community composition and density resulted in a contrast in their ability to produce biomass in NWC zones at the different sampling stages (Supplementary Table 3). Across all crop stages, weed biomass was generally low in C5, intermediate in C1, C3 and C4, and highest in C2 and C6 (Table 1). C1, $\mathrm{C} 2$ and $\mathrm{C} 6$ reached maximum weed biomass at heading, whereas $\mathrm{C} 4$ reached it at filling. Weed biomass remained stable across the different crop stages in C3 and C5 (Table 1). All diversity indices based on biomass were affected by WCC (Supplementary Table 3). Species richness was not significantly different between WCCs at elongation, but $\mathrm{C} 3$ and $\mathrm{C} 4$ presented a much more species-rich community at maturity (Table 1 ). Evenness of weed biomass was lowest in C2, intermediate in C1, C4, C5 and C6, and highest in C3 (Table 1). Shannon diversity index and Rao's quadratic entropy followed a similar trend (Table 1).

Effect of weed communities on grain yield and yield components. In SWC zones, comparison of weed-free and weedy quadrats within each WCC did not reveal any differences in terms of yield component or grain yield (Table 2). In NWC zones, C1, C2, C5 and C6 generated significant reductions in the number of ears per plant of $22 \%, 39 \%$, $16 \%$ and $31 \%$, respectively (Table 2). C1, C2, C5 and C6 also generated significant reductions in the number of grains per ear of $12 \%$, $34 \%, 11 \%$ and $19 \%$, respectively (Table 2 ). Only C6 was able to generate a significant reduction (19\%) of 1,000-kernel weight (Table 2). $\mathrm{C} 3$ and $\mathrm{C} 4$ did not significantly affect yield components or grain yield in NWC zones. Finally, C1, C2, C5 and C6 resulted in significant reductions in grain yield of $25 \%, 56 \%, 19 \%$ and $51 \%$, respectively (Table 2). The inclusion of WCC in the grain yield model on 
Table 1 | Characteristics of WCCs

\begin{tabular}{|c|c|c|c|c|c|c|}
\hline & \multirow[b]{2}{*}{ WCC } & \multirow[b]{2}{*}{ Initial } & \multicolumn{4}{|c|}{ Crop stage } \\
\hline & & & Elongation & Heading & Filling & Maturity \\
\hline \multirow[t]{6}{*}{ Initial weed density } & $\mathrm{C} 1$ & $47(8) a b$ & - & - & - & - \\
\hline & $\mathrm{C} 2$ & $147(36) c$ & - & - & - & - \\
\hline & $\mathrm{C} 3$ & $64(13) b$ & - & - & - & - \\
\hline & $\mathrm{C} 4$ & $25(6) a$ & - & - & - & - \\
\hline & C5 & $83(18) b c$ & - & - & - & - \\
\hline & $\mathrm{C} 6$ & 87 (19) bc & - & - & - & - \\
\hline \multirow[t]{6}{*}{ Weed biomass $\left(\mathrm{g} \mathrm{DM} \mathrm{m}^{-2}\right.$ ) } & $\mathrm{C} 1$ & - & $43(15) a b$ & $104(36) a b$ & $149(51) b$ & $149(51) b$ \\
\hline & $\mathrm{C} 2$ & - & $64(24) a b$ & $179(66) b$ & $223(82) b$ & $206(76) b$ \\
\hline & $\mathrm{C} 3$ & - & $71(28) b$ & $63(25) a b$ & $114(45) a b$ & $106(42) a b$ \\
\hline & C4 & - & $28(10) a$ & $45(17) a$ & $173(66) b$ & $101(38) a b$ \\
\hline & $\mathrm{C} 5$ & - & $34(12) a b$ & $61(22) a$ & $56(20) a$ & $57(20) a$ \\
\hline & $\mathrm{C} 6$ & - & $55(20) a b$ & $119(43) a b$ & $174(64) b$ & $157(57) b$ \\
\hline \multirow[t]{6}{*}{ Species richness } & $\mathrm{C} 1$ & $3.4(0.3)$ & $8.1(0.9)$ & $9.2(1.0) b$ & $6.4(0.7) a b$ & $4.4(0.5) b$ \\
\hline & $\mathrm{C} 2$ & $2.8(0.4)$ & $5.2(0.6)$ & $4.9(0.6) a$ & $5.2(0.6) a$ & $2.7(0.3) a$ \\
\hline & $\mathrm{C} 3$ & $3.4(0.4)$ & $8.4(1.1)$ & $8.6(1.1) b$ & $9.2(1.2) b$ & $9.4(1.2) \mathrm{c}$ \\
\hline & $\mathrm{C} 4$ & $2.8(0.4)$ & $8.3(1.0)$ & $5.9(0.7) a b$ & $7.0(0.9) a b$ & $7.6(0.9) c$ \\
\hline & C5 & $4.1(0.5)$ & $5.9(0.6)$ & $6.2(0.7) a b$ & $5.7(0.6) a b$ & $4.4(0.5) b$ \\
\hline & $\mathrm{C} 6$ & $3.7(0.5)$ & $6.8(0.8)$ & $6.4(0.8) a b$ & $5.0(0.6) a$ & $3.7(0.4) a b$ \\
\hline \multirow[t]{6}{*}{ Shannon diversity index } & $\mathrm{C} 1$ & $0.72(0.10) b$ & $0.44(0.07) b c$ & & & \\
\hline & $\mathrm{C} 2$ & $0.17(0.07) a$ & $0.14(0.05) a$ & & & \\
\hline & $\mathrm{C} 3$ & $0.69(0.10) b$ & $1.27(0.17) d$ & & & \\
\hline & C4 & $0.57(0.13) a b$ & $0.66(0.10) b c$ & & & \\
\hline & C5 & $1.02(0.14) b$ & $0.83(0.10) \mathrm{cd}$ & & & \\
\hline & C6 & $0.80(0.14) b$ & $0.42(0.09) b$ & & & \\
\hline \multirow[t]{6}{*}{ Evenness } & $\mathrm{C} 1$ & $0.62(0.08) b$ & $0.32(0.06) b c$ & & & \\
\hline & $\mathrm{C} 2$ & $0.17(0.06) \mathrm{a}$ & $0.11(0.03)$ a & & & \\
\hline & $\mathrm{C} 3$ & $0.58(0.08) b$ & $0.63(0.08) d$ & & & \\
\hline & $\mathrm{C} 4$ & $0.53(0.11) a b$ & $0.45(0.08) \mathrm{bcd}$ & & & \\
\hline & $\mathrm{C} 5$ & $0.70(0.07) b$ & $0.44(0.07) \mathrm{cd}$ & & & \\
\hline & $\mathrm{C} 6$ & $0.60(0.10) b$ & $0.24(0.06) a b$ & & & \\
\hline \multirow[t]{6}{*}{ Rao's quadratic entropy } & $\mathrm{C} 1$ & $1.83(0.34) b$ & $1.29(0.33) a b$ & & & \\
\hline & $\mathrm{C} 2$ & $0.30(0.22) a$ & $0.24(0.17) a$ & & & \\
\hline & $\mathrm{C} 3$ & $2.24(0.42) b$ & $4.49(0.84) c$ & & & \\
\hline & C4 & $2.21(0.61) b$ & $2.24(0.51) b c$ & & & \\
\hline & C5 & $2.26(0.44) b$ & $1.24(0.33) a b$ & & & \\
\hline & C6 & $3.49(0.70) b$ & $1.50(0.43) b$ & & & \\
\hline
\end{tabular}

Characteristics of WCCs are based either on initial density data (measured in January-February) across both NWC and SWC zones or on biomass data measured later in the season in NWC zones (measured from wheat stem elongation to maturity, that is, April to July). Numbers in parentheses represent standard error around least squares means (back transformed from the log scale (initial weed density, weed biomass, species richness), square root scale (Shannon diversity index, Rao's quadratic entropy) or logit scale (evenness), averaged across years). Lowercase letters show significant differences between groups at $P<0.05$. Least squares means of Shannon diversity index, evenness or Rao's quadratic entropy computed on the basis of biomass data are shown across crop stages, because the interaction between WCC and crop stage was not significant.

top of management type and hand weeding led to an increase in the coefficient of determination (from 0.68 to 0.85 for the fixed effects; Supplementary Table 1b).

Disentangling the relationships between weed biomass, weed diversity and crop productivity. Evenness and Shannon diversity index presented nearly identical results (Supplementary Tables 4-8). Therefore, of these two metrics, only evenness is presented. However, species richness (based on biomass or density) had no effect on crop or weed biomass.
Weed diversity and crop biomass. Crop biomass was positively correlated with weed evenness (based on density and biomass) and Rao's quadratic entropy (based on biomass) (Supplementary Tables 4 and 5). No significant interaction with crop stage was detected for any of the diversity indicators. As evenness of weed biomass increased from 0 to 1 , crop biomass increased by $23 \%(+98,+174,+263$ and $+262 \mathrm{~g} \mathrm{DM} \mathrm{m}^{-2}$ at stem elongation, heading, grain filling and maturity, respectively) ( $R^{2}$ fixed effects $=0.83$; Fig. 2$)$. Similar effects were obtained with evenness based on density (that is, crop productivity increased by $27 \%$ as evenness increased from 0 to $1 ; R^{2}$ fixed 

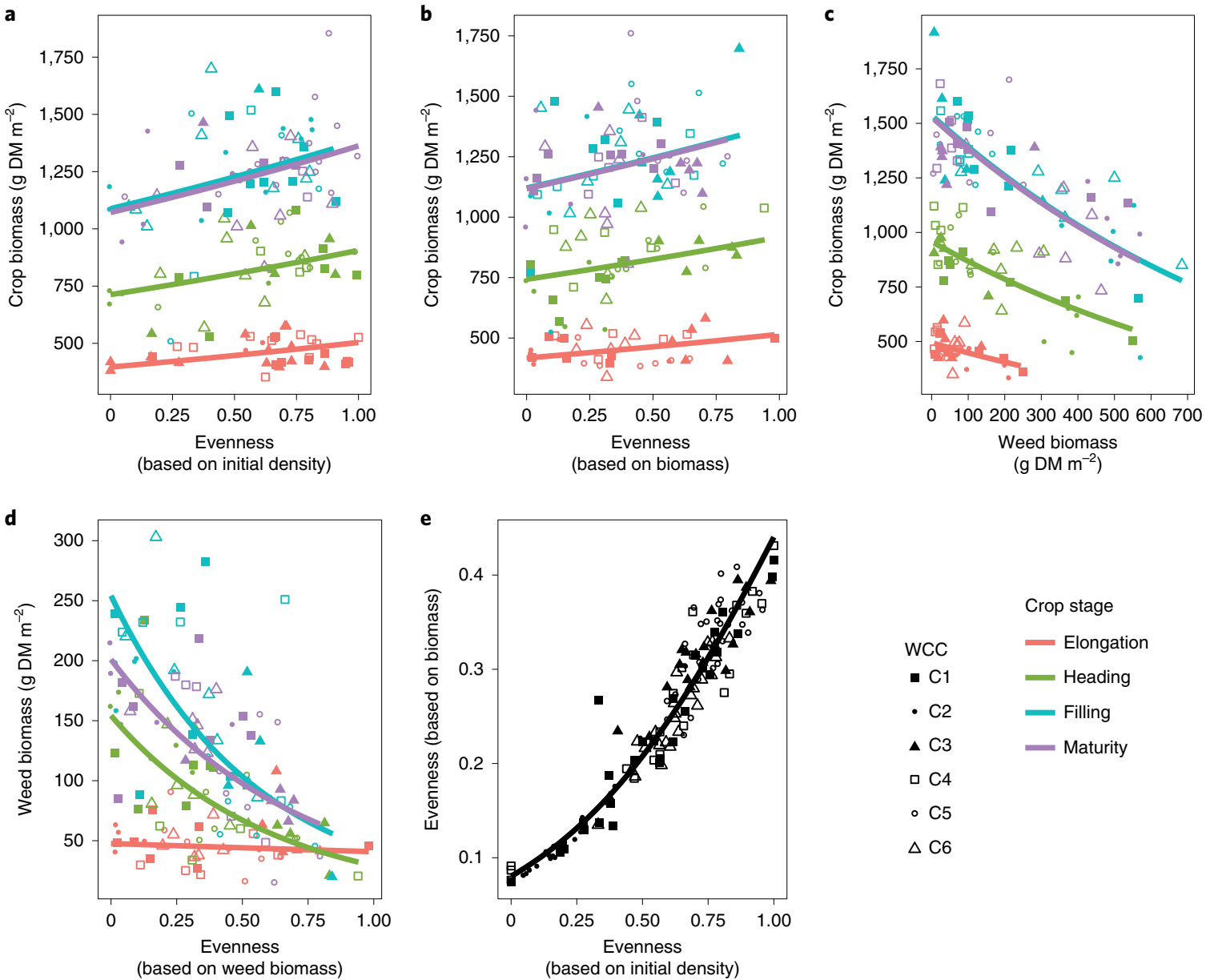

Fig. 2 | Conditional plots highlighting the relationships between crop biomass, weed biomass and evenness based on density or biomass. a, Evenness based on initial density data and wheat productivity at four crop stages. b. Evenness based on biomass data and wheat productivity at four crop stages. c. Weed biomass and wheat productivity at four crop stages. d, Evenness based on biomass data and weed biomass at four crop stages. e, Evenness based on initial density data and evenness based on biomass data. Predictions were based on linear (a-d) or generalized (e) mixed effects models taking into account random effects. For graphical purposes, crop and weed biomass responses (a-d) were back transformed from the log scale, and evenness based on biomass data (e) was back transformed from the logit scale. Regression lines represent population-level predictions (that is, predictions not considering random effects). Points show partial residuals. For a-c and $\mathbf{e}$ regression lines were computed on the reduced model considering the interaction with crop stage was not significant. For $\mathbf{e}$, the non-significant crop stage effect was also dropped from the model. Year was considered as an a priori covariate for all models (fixed at 2016), whereas wheat density (fixed at 214 plants per $\mathrm{m}^{2}$ ) was considered as an a priori covariate for the models resulting in a-d.

effects $=0.83$ ) and Rao's quadratic entropy based on biomass (that is, crop productivity increased by $19 \%$ over the observed gradient; $R^{2}$ fixed effects $=0.83$ ). Crop biomass at maturity can be interpreted as a proxy for grain yield, considering the strength of the correlation between the two variables (Pearson's product-moment correlation, $t=11.545$, d.f. $=33, P<0.0001, r=0.89)$.

Weed biomass and crop biomass. Crop biomass was negatively correlated with weed biomass $\left(R^{2}\right.$ fixed effects $=0.84$; Supplementary Table 5). No significant interaction between weed biomass and crop stage was detected. As weed biomass increased from 0 to $100 \mathrm{~g} \mathrm{DM} \mathrm{m}^{-2}$, crop biomass decreased by $9 \%(-48,-91,-145$ and $-146 \mathrm{~g} \mathrm{DM} \mathrm{m}^{-2}$ at stem elongation, heading, grain filling and maturity, respectively) (Fig. 2).

Weed biomass and weed diversity. Weed biomass was negatively correlated with evenness based on weed biomass, and the intensity of the relationship depended on crop stage (Supplementary Table 7). No significant relationships were detected for evenness based on density or Rao's quadratic entropy (whether based on density or biomass). The slopes between evenness of weed biomass and weed biomass were steeper at heading $\left(\beta_{\text {log scale }}=-1.67\right)$ and filling $\left(\beta_{\log \text { scale }}=-1.80\right)$ than at elongation $\left(\beta_{\log \text { scale }}=-0.15\right)$. As evenness of weed biomass increased from 0 to 1 , weed biomass decreased by $14 \%, 81 \%, 83 \%$ and $76 \%$ at crop stem elongation, heading, grain filling and maturity, respectively (Fig. 2). Evenness based on biomass could be modelled as a simple function of evenness based on initial density (that is, no significant effect of crop stage or crop stage by evenness interaction; Supplementary Table 8 and Fig. 2).

\section{Discussion}

Not all weed communities are detrimental to crop productivity. In accordance with Oerke ${ }^{2}$, average grain yield was reduced by $30 \%$ across all weed communities in unweeded zones, whereas yield loss was not significant in zones where weeds were managed. However, this average value masked a great variability. Our hypothesis that not all weed communities generate significant yield losses was validated. Four out of the six weed communities (C1, C2, C5 and C6) 
Table 2 | Pre-planned contrasts between weed-free and weedy quadrats

\begin{tabular}{|c|c|c|c|c|c|c|}
\hline Management type & Response variables & WCC & Weed-free & Weedy & $\%$ difference & $P$ value \\
\hline \multirow[t]{22}{*}{ SWC } & \multirow[t]{5}{*}{ Number of ears per plant } & $\mathrm{C} 1$ & $2.50(0.14)$ & $2.52(0.13)$ & -1 & 0.92 \\
\hline & & $\mathrm{C} 2$ & - & - & - & - \\
\hline & & C4 & - & - & - & - \\
\hline & & C5 & $2.43(0.17)$ & $2.31(0.17)$ & 5 & 0.55 \\
\hline & & $\mathrm{C} 6$ & $2.87(0.41)$ & $2.55(0.36)$ & 11 & 0.49 \\
\hline & \multirow[t]{6}{*}{ Number of grains per ear } & $\mathrm{C} 1$ & $31.3(1.2)$ & $32.0(1.2)$ & -2 & 0.65 \\
\hline & & $\mathrm{C} 2$ & - & - & - & - \\
\hline & & C3 & $32.0(1.1)$ & $31.7(1.1)$ & 1 & 0.84 \\
\hline & & C4 & - & - & - & - \\
\hline & & C5 & $27.0(1.3)$ & $27.4(1.3)$ & -1 & 0.79 \\
\hline & & C6 & $35.2(3.3)$ & $33.8(3.1)$ & 4 & 0.74 \\
\hline & \multirow{5}{*}{ 1,000-kernel weight (g) } & $\mathrm{C} 2$ & - & - & - & - \\
\hline & & $\mathrm{C} 3$ & $34.5(1.1)$ & $34.9(1.1)$ & -1 & 0.63 \\
\hline & & C4 & - & - & - & - \\
\hline & & $\mathrm{C} 5$ & $35.6(1.5)$ & $36.7(1.5)$ & -3 & 0.39 \\
\hline & & $\mathrm{C} 6$ & $33.5(2.7)$ & $34.6(2.7)$ & -3 & 0.64 \\
\hline & \multirow[t]{6}{*}{ Grain yield $\left(\mathrm{g} \mathrm{m}^{-2}\right)$} & $\mathrm{C} 1$ & $605(36)$ & $636(37)$ & -5 & 0.54 \\
\hline & & $\mathrm{C} 2$ & - & - & - & - \\
\hline & & $\mathrm{C3}$ & $529(31)$ & $532(31)$ & -1 & 0.95 \\
\hline & & C4 & - & - & - & - \\
\hline & & C5 & $524(41)$ & $536(42)$ & -2 & 0.83 \\
\hline & & C6 & $711(111)$ & $659(103)$ & 7 & 0.72 \\
\hline \multirow[t]{23}{*}{ NWC } & \multirow[t]{5}{*}{ Number of ears per plant } & $\mathrm{C} 1$ & $2.42(0.13)$ & $1.90(0.11)$ & 22 & 0.0004 \\
\hline & & C3 & $1.92(0.13)$ & $1.94(0.13)$ & -1 & 0.87 \\
\hline & & C4 & $2.34(0.15)$ & $2.12(0.14)$ & 9 & 0.2 \\
\hline & & $\mathrm{C} 5$ & $2.21(0.12)$ & $1.86(0.10)$ & 16 & 0.0096 \\
\hline & & C6 & $2.09(0.13)$ & $1.43(0.09)$ & 31 & $<0.0001$ \\
\hline & \multirow[t]{6}{*}{ Number of grains per ear } & $\mathrm{C} 1$ & $30.5(1.1)$ & $26.7(1.0)$ & 12 & 0.0094 \\
\hline & & $\mathrm{C} 2$ & $32.4(1.4)$ & $21.5(1.0)$ & 34 & $<0.0001$ \\
\hline & & $\mathrm{C} 3$ & $34.0(1.5)$ & $31.1(1.4)$ & 9 & 0.1 \\
\hline & & $\mathrm{C} 4$ & $33.5(1.4)$ & $31.6(1.3)$ & 6 & 0.29 \\
\hline & & $\mathrm{C} 5$ & $31.0(1.1)$ & $27.6(1.0)$ & 11 & 0.015 \\
\hline & & C6 & $30.3(1.2)$ & $24.5(1.0)$ & 19 & 0.001 \\
\hline & \multirow[t]{6}{*}{ 1,000-kernel weight (g) } & $\mathrm{C} 1$ & $34.9(1.1)$ & $34.6(1.1)$ & 1 & 0.76 \\
\hline & & $\mathrm{C} 2$ & $33.4(1.2)$ & $33.0(1.4)$ & 1 & 0.8 \\
\hline & & $\mathrm{C} 3$ & $34.9(1.4)$ & $36.5(1.4)$ & -5 & 0.17 \\
\hline & & C4 & $34.0(1.3)$ & $34.9(1.3)$ & -3 & 0.42 \\
\hline & & $\mathrm{C} 5$ & $35.0(1.2)$ & $35.5(1.2)$ & -1 & 0.63 \\
\hline & & C6 & $35.3(1.2)$ & $28.6(1.1)$ & 19 & $<0.0001$ \\
\hline & \multirow[t]{6}{*}{ Grain yield $\left(\mathrm{g} \mathrm{m}^{-2}\right)$} & $\mathrm{C} 1$ & $560(34)$ & $419(25)$ & 25 & 0.0007 \\
\hline & & $\mathrm{C} 2$ & $588(42)$ & $258(18)$ & 56 & $<0.0001$ \\
\hline & & $\mathrm{C3}$ & $534(40)$ & $522(39)$ & 3 & 0.78 \\
\hline & & $\mathrm{C} 4$ & $588(41)$ & $538(38)$ & 8 & 0.35 \\
\hline & & $\mathrm{C} 5$ & $548(33)$ & $445(27)$ & 19 & 0.01 \\
\hline & & C6 & $518(35)$ & $254(17)$ & 51 & $<0.0001$ \\
\hline
\end{tabular}

Pre-planned contrasts between weed-free and weedy quadrats are shown within each combination of management type (SWC and NWC) and WCC (C1 to C6) for three different yield components (number of ears per plant, number of grains per ear and 1,000-kernel weight) and grain yield. Covariates (number of plants per $\mathrm{m}^{2}$, number of ears per $\mathrm{m}^{2}$ or number of grains per $\mathrm{m}^{2}$ ) were set to their means for comparison. Numbers in parentheses represent standard error around least squares means (back transformed from the log scale, averaged across years). Bold $P$ values indicate significant differences $(P \leq 0.05)$. Weed communities $C 2$ and $C 4$ were not observed in SWC zones. 
were able to generate significant yield losses, and these potential yield losses ranged from 19 to $56 \%$. Such a contrasting effect of different weed communities on yields was reflected in the increase of the coefficient of determination (from 0.68 to 0.83 ) when weed communities were added in the grain yield model. It justifies the need to consider not simply weed presence or absence but also different weed communities that each exert a specific effect on grain yields.

Differences in total weed density between the six weed communities did not necessarily reflect their impact on crop yield, highlighting that weed community composition is of great importance in determining the effect of weed communities on crop yield. The four communities capable of generating yield loss were characterized by an initial weed density of 47 to 147 plants per $\mathrm{m}^{2}$ and a large proportion of ALOMY and/or GALAP. The fact that C1 and C5 generated similar levels of yield losses (19-25\%) even though weed density was $77 \%$ higher in C5 highlights a greater competitive potential of $\mathrm{C} 1$ over $\mathrm{C} 5$. Indeed, weed density in $\mathrm{C} 1$ showed a large proportion of ALOMY (51\%), a species that mimics the crop (it is phylogenetically close and has the same germination period, similar height and a slightly shorter cycle, inducing resource pre-emption), whereas C5 was mainly composed of VERHE (26\%) and VIOAR (46\%), two short, broadleaved species capable of completing their cycle before crop flowering ${ }^{33}$. Similarly, C2 (90\% ALOMY) and C6 (30\% ALOMY and 36\% GALAP) generated similar levels of yield losses (51-56\%) even though weed density was $69 \%$ higher in C2. This could highlight GALAP's greater competitive potential over ALOMY. Indeed, GALAP is characterized by greater values for seed mass, nitrophily index, specific leaf area and height and has a longer life cycle than ALOMY, which could confer an advantage in terms of establishment and resource acquisition ${ }^{22,23,27}$. In contrast, C5 and C6 presented nearly identical initial weed densities, but C6 led to a reduction of grain yield more than twice as large (19\% versus 51\%). This suggests differences in competitive trait values between the two communities ${ }^{22,27,31,34}$ and highlights why weed density thresholds have had limited applications ${ }^{17,19}$.

$\mathrm{C} 1, \mathrm{C} 2$ and $\mathrm{C} 5$ generated yield losses through a reduction of the number of ears per plant and the number of grains per ear, whereas C6 impacted all yield components. Such results suggest that C1, C2 and C5 competed with the crop until the time of crop flowering, whereas C6 competed with the crop until grain filling ${ }^{32}$. Whether competition for light and/or soil resources affected these yield components needs further investigation, especially in low-input cropping systems in which soil nutrients could be limiting ${ }^{33,34}$. We did not detect any weed community capable of affecting yield components determined later in the season without reducing the number of ears per plant first ${ }^{33,35}$. This is in line with the fact that weed-crop interference starts earlier than crop flowering ${ }^{36}$, which is often considered the critical stage of weed-crop interference. Such findings have justified the definition of a critical weed-free period ${ }^{37}$ but also suggest that late-emerging weeds are not detrimental to crop production ${ }^{28}$. The reduction of 1,000-kernel weight generated by C6 could reflect GALAP's demand for resources for late growth and its ability to climb on top of the crop, generating competition for light and soil resources during grain filling ${ }^{38-40}$.

Focusing only on weed biomass sampled late in the season may limit our understanding of weed-crop interference. The ability of a species to produce biomass is often considered a proxy for its competitive effect, but some traits may play an important role as well ${ }^{16,27,34,36}$. Even though weed biomass sampled late in the season is thought to integrate weed-crop interference throughout the crop cycle, it does not allow identification of which yield component participated most in the reduction of grain yield. Weed biomass at stem elongation and the percent loss of ears per plant appeared positively related. However, C3 seemed to deviate from these relationships, suggesting that aboveground weed biomass does not capture all the relevant aspects of competition, such as potential niche complementarity between the weed community and the crop stand ${ }^{16,22,24,30,31}$. A high functional diversity of traits reflecting plant strategies could explain why $\mathrm{C} 3$ was able to produce so much biomass without impacting the $\mathrm{crop}^{24}$. In contrast, the absence of weed-crop interference in C4 could be attributed to low initial weed density and a competitive crop $^{11,20}$, reflected by low weed biomass at stem elongation and its stability in time. Moreover, C6 showed similar weed biomass at grain filling and maturity to other communities but was the only community capable of reducing 1,000-kernel weight. This result hints that a greater understanding of how weed-crop interference relates to yield components should rely not only on weed biomass but also on how it is formed in time (that is, the shape of growth curves) and space (that is, growth form, ability to climb and maximum plant height).

Weed diversity mitigates crop yield loss. The hypothesis that higher weed diversity limits yield losses through reduced weed biomass production was also validated. The effects of weed community evenness and weed biomass on crop productivity could not be disentangled. When weed community evenness was high, weed biomass was low and weed-crop interference was alleviated. Hence, we could not test whether more diversified weed communities limited yield losses for the same level of weed biomass, which we would consider a 'true' biodiversity effect. However, Rao's quadratic entropy based on biomass was positively correlated with crop productivity even though no relationship with weed biomass was detected. This could hint that, irrespective of weed community biomass, a greater diversity of traits within the weed community limits intense niche overlap with the crop and hence yield losses ${ }^{21}$. Increasing species richness most likely had no effect on crop productivity or weed biomass because environmental filtering and competition constrain the number of competitive weed species that are locally adapted and abundant ${ }^{14}$.

In accordance with Cierjacks et al. ${ }^{24}$, we highlighted a positive relationship between evenness (whether computed on the basis of biomass or density) and crop productivity at the four crop stages. Such results are of considerable importance because they stress the fact that high crop productivity and diverse weed communities can be achieved simultaneously in winter cereals. These relationships do not imply that high crop productivity is necessarily associated with high weed diversity but rather that, in the presence of weeds, high evenness limits the probability of dominant and competitive species susceptible of generating important yield losses ${ }^{5,10,25}$. Similarly, high crop productivity could also be reached with a high density of weak competitors $^{28}$, as in C3. Based on these results, weed management decisions should take into account weed community diversity, and weeding operations should target competitive and dominant spe$\operatorname{cies}^{25}$. However, current weed control practices do not easily allow targeting a specific species in a complex community ${ }^{41}$. Weed diversity should rather be indirectly promoted by diversifying cropping systems (crop rotation ${ }^{5}$, crop mixtures, cover crops or grazing ${ }^{42}$ ), which should also alleviate weed-crop interference by broadening weed species niches through a more diverse pool of resources ${ }^{30}$.

According to the community assembly framework, a diversity of weak filters should allow the persistence of a diverse weed community at density levels that should limit, if not prevent, yield losses $^{43}$. Nevertheless, increased weed diversity could also promote the recruitment of a few problematic species, so careful monitoring is required for early and adapted management ${ }^{14}$. Although this study only considered weed-crop interference, it is important to note that weeds could also increase production costs, complicate harvest operations, reduce sale price by polluting harvested goods or jeopardize long-term weed management by increasing the soil seedbank ${ }^{14}$.

Further research is needed to confirm the generality of our relationship between evenness (based on biomass data) and weed 
biomass, that is, whether or not highly even weed communities could produce high weed biomass. Although this appears possible in experimental conditions, we argue that such conditions are rarely met in the vast majority of agroecosystems ${ }^{25}$. Even if multiple competitive species are present at the local scale of competition (that is, the quadrat), species traits interact with the environment and one species may be dominant one year and subordinate the next ${ }^{27,31}$. Moreover, competitive and dominant species might reduce the fitness of subordinate species, which may decrease in abundance over time $\mathrm{e}^{20,23,27,44}$.

\section{Conclusions}

Through a detailed description of naturally assembled weed communities and analysis of their effect on yield components in a multiyear and multi-site field experiment, we assessed that grain yield losses due to weeds ranged from negligible to $56 \%$ and were achieved through differing pathways, highlighting that not all weed communities were detrimental to crop productivity. Moreover, we addressed one of the top ranked questions in weed science: can weed diversity mitigate yield losses? The effects of weed biomass and weed diversity on crop productivity could not be disentangled because higher levels of weed diversity reduced the probability of occurrence of dominant and competitive species. Therefore, high levels of weed diversity were associated with low weed biomass and reduced interference with the crop. Further experiments could attempt to disentangle these two effects on crop productivity by artificially assembling weed communities with similar biomass production across a gradient of functional diversity. Nevertheless, we provide evidence that high crop productivity and weed diversity can be reached simultaneously in winter cereals. Weed diversity could therefore be used to detect productive and environmentally friendly cropping systems.

\section{Methods}

Experimental site and set-up. The field experiment was conducted over three winter cereal growing seasons from sowing 2015 to harvest 2018 at the INRA (Institut National de la Recherche Agronomique, that is the French National Institute for Agricultural Research) experimental farm near Dijon, northeastern France $\left(47^{\circ} 14^{\prime} 11.2^{\prime \prime} \mathrm{N}, 5^{\circ} 5^{\prime} 56.1^{\prime \prime} \mathrm{E}\right)$. The site is subject to a semi-continental climate (Supplementary Fig. 3), characterized by cold winters and hot summers (Supplementary Methods). Plots presented a calcareous bedrock, an average soil texture of $50 \%$ clay, $44 \%$ silt and $6 \%$ sand and a soil depth ranging from 0.5 to $0.9 \mathrm{~m}$

For each winter cereal cropping season $\left(N_{\text {year }}=3\right)$, the experiment was nested in two different plots $\left(N_{\text {plots }}=6\right.$; five with winter wheat (Triticum aestivum $\mathrm{L}$.) and one with winter barley (Hordeum vulgare L.)) of a long-term integrated weed management cropping system experiment (2001-2018) ${ }^{45}$. The experiment included five cropping systems replicated in two blocks (plot size $=1.7 \mathrm{ha}$ ): one conventional reference system and four alternative cropping systems. The cropping systems differed mainly by their crop sequence (three versus six years), tillage type (gradient from no-till to systematic ploughing) and weeding strategy (gradient from chemical only to mechanical only). Over time, these contrasting sets of practices acted as filters and shaped contrasted weed communities ${ }^{43}$.

For each combination of plot and year (Supplementary Fig. 4), nine $16 \mathrm{~m}^{2}$ zones were selected $\left(N_{\text {zones }}=54\right)$ during the winter period: six were subject to no weed control $\left(N_{\mathrm{NWC}}=36\right)$ and three were subject to standard weed control $\left(N_{\mathrm{SwC}}=18\right)$, that is, harrowing, herbicides or both (Supplementary Table 9 details all agricultural practices). During herbicide applications, NWC zones were protected with a $150 \mu \mathrm{m}$ waterproof silage tarp, whereas the harrow was lifted up in the case of mechanical weeding. The weed spatial distribution was visually assessed by scouting the whole field. This allowed us to position the zones for each management type (NWC or SWC) to obtain a representative view of the weed flora in the field. Within each zone, five $0.83 \mathrm{~m}^{2}$ quadrats (six crop rows with $13.8 \mathrm{~cm}$ row spacing) with similar weed communities (natural 'replicates') were positioned and maintained fixed during the growing season: one 'weedy' quadrat for each biomass sampling (done at four crop growth stages: stem elongation, heading, grain filling and maturity) and one additional 'weed-free' quadrat sampled at maturity (hand weeded throughout the season) $\left(N_{\text {quadrats }}=270\right)$.

Weed and crop sampling. Crop and weed density per species were assessed in all 270 quadrats from December to January (the coldest period, in which weed germinations are rare), that is, before (2017 and 2018) or between (2016) weeding operations (Supplementary Fig. 4). Hence, all seedlings counted at this stage resulted from late-autumn germinations.
Aboveground crop and weed biomass were sampled at four different critical development stages of winter cereals: stem elongation (20 April to 2 May), heading (10 May to 19 May), grain filling (7 June to 16 June) and maturity (27 June to 12 July) (Supplementary Fig. 4). Weed biomass was collected per species to compute diversity indices based on biomass. Samples were then oven-dried for $48 \mathrm{~h}$ at $80^{\circ} \mathrm{C}$ and weighed. Weed biomass per species was pooled at the quadrat level to obtain total weed biomass per quadrat.

Crop yield components were assessed in the quadrats sampled at maturity. Three yield components elaborated at different stages of the crop cycle were assessed to trace back in time the effect of weed-crop interference across the different weed communities: the number of ears per plant, the number of grains per ear and the 1,000-kernel weight. The number of ears per plant is elaborated from tillering to mid-elongation ${ }^{32}$ and was obtained by dividing the number of ears per quadrat by crop density per quadrat. The number of grains per ear is elaborated up to crop flowering ${ }^{32}$ and was obtained by dividing the number of grains per quadrat by the number of ears per quadrat. The 1,000-kernel weight is elaborated from flowering to maturity $y^{32}$ and was computed by averaging the weight of four random and independent samples of 1,000 kernels per quadrat. After drying, total crop biomass at maturity (ears and straw) was submitted to a fixed station threshing machine to assess grain yield (at $0 \%$ humidity).

Numerical and statistical analysis. Weed diversity measures. Diversity of weed communities was characterized through three taxonomic indices (species richness, Shannon diversity index and Pielou's evenness index) and one functional index (Rao's quadratic entropy), computed on either weed density or weed biomass (Supplementary Methods). Species richness $(S)$ was computed as the number of species per quadrat. Shannon diversity index and evenness were computed as in Scheiner ${ }^{39}$. To fully explore the gradient of evenness, monospecific weed 'communities' were attributed the lowest evenness value possible (that is, 0 ). Rao's quadratic index ${ }^{46}$ was computed on three numeric traits reflecting plant strategies ${ }^{47}$ : canopy height, seed mass and specific leaf area. All trait values were extracted from the LEDA (Life-history traits of the Northwest European flora: a database) trait database ${ }^{48}$. Rao's quadratic index was computed with the FD (functional diversity) function of the R FD package ${ }^{49}$. Abundance was weighted by either density or biomass.

Classification of weed communities. Before classifying zones based on their weed communities, permutational multivariate analysis of variance (that is, PERMANOVA, calculated using the $\mathrm{R}$ function adonis 2 of the vegan package) was carried out on the Bray-Curtis dissimilarity matrix of all 216 weedy quadrats (54 zones). The analysis allowed us to quantify the percentage of weed community variability explained by zones and hence verify that quadrats within the same zone showed similar weed communities. Due to the complexity of the design and the absence of adapted techniques, no permutation tests were performed.

Weed communities were classified at the zone level (average community across the four quadrats, the fifth being weed free) by running a hierarchical cluster analysis ( $\mathrm{R}$ function hclust of the stats package) based on Ward's clustering criterion on a Bray-Curtis dissimilarity matrix (which takes into account species identity and abundance) of the initial weed density counts. The number of clusters was determined to explain $80 \%$ of inertia and hence provide a fine discrimination of weed communities. Principal coordinates analysis (PCoA) on the square root (to obtain a fully Euclidean ordination) of the Bray-Curtis dissimilarity matrix was performed using the $\mathrm{R}$ function wcmdscale of the vegan package to display the classification of zones in a multivariate space.

Mixed effects models. All regression analysis were carried out with the $\mathrm{R}$ software version $3.3 .2^{49}$ at the quadrat level. Generalized linear mixed effects models (GLMM) and linear mixed effects models (LMM) were performed to account for the nature of certain response variables (Supplementary Methods) and the hierarchical design of the experiment (zones nested in plots). Year and weed communities were always treated as fixed factors.

Description of weed communities. To highlight differences between weed communities across all weedy quadrats, weed density and diversity indicators based on density were regressed against year and weed communities. A crop stage and weed community by crop stage effect was added to the previous model to analyse weed biomass or diversity indicators based on biomass data at the four crop stages. Only weedy quadrats of NWC zones were considered.

Identification of weed communities that minimize yield loss. Potential and actual yield losses due to management type (NWC or SWC) and hand weeding were highlighted by regressing yield against year, crop density, management type, hand weeding and management type $\times$ hand weeding. Only the subset of quadrats sampled at maturity was considered. For each combination of management type and WCC, pre-planned contrasts between weed-free and weedy quadrats were carried out for all three yield components and grain yield. The importance of considering different weed communities was investigated by comparing the latter model with a model including year, crop density and all possible interactions between weed communities, management type and hand weeding. The effect 
of weed communities on yield components was analysed identically, except that crop density was used as a covariate only for the analysis of the number of ears per plant. It was replaced by ear density for the analysis of the number of grains per ear and by grain density for the analysis of 1,000-kernel weight (Supplementary Methods)

Disentangling the relationships between weed biomass, weed diversity and crop productivity. The relationship between crop (or weed) biomass and diversity indicators (based on either density or biomass) in weedy quadrats of NWC zones was investigated by regressing crop (or weed) biomass against year, crop density, diversity indicators, crop stage and diversity indicators $\times$ crop stage. The relationship between crop and weed biomass was analysed identically. The relationships between diversity indicators based on biomass and their reciprocal based on density in weedy quadrats of NWC zones were analysed by regressing diversity indicators based on biomass against year, their reciprocal based on density, crop stage and their reciprocal based on density $\times$ crop stage. See Supplementary Methods for further information on data analysis.

\section{Data availability}

The data that support the findings of this study are available from the corresponding author upon request.

\section{Code availability}

The code used to analyse the data and produce the figures is available from the corresponding author upon request.

Received: 16 April 2019; Accepted: 23 September 2019; Published online: 11 November 2019

\section{References}

1. Milberg, P. \& Hallgren, E. Yield loss due to weeds in cereals and its large-scale variability in Sweden. Field Crops Res. 86, 199-209 (2004)

2. Oerke, E. C. Crop losses to pests. J. Agric. Sci. 144, 31-43 (2006)

3. Foley, J. A. et al. Solutions for a cultivated planet. Nature 478, 337-342 (2011).

4. Heap, I. in Integrated Pest Management: Pesticide Problems Vol. 3 (eds Pimentel, D. \& Peshin, R.) 281-301 (Springer, 2014).

5. Storkey, J. \& Neve, P. What good is weed diversity? Weed Res. 58, 239-243 (2018)

6. Malik, N. \& Vanden Born, W. H. The biology of canadian weeds. 86. Galium aparine L. and Galium spurium L. Can. J. Plant Sci. 68, 481-499 (1988).

7. Naylor, R. E. L. Aspects of the population dynamics of the weed Alopecurus myosuroides Huds. in winter cereal crops. J. Appl. Ecol. 9, 127-139 (1972)

8. Jordan, N. \& Vatovec, C. in Weed Biology and Management (ed. Inderjit, S.) 137-158 (Springer, 2004).

9. Marshall, E. J. P. et al. The role of weeds in supporting biological diversity within crop fields. Weed Res. 43, 77-89 (2003).

10. Neve, P. et al. Reviewing research priorities in weed ecology, evolution and management: a horizon scan. Weed Res. 58, 250-258 (2018).

11. Guglielmini, A., Verdú, A. \& Satorre, E. Competitive ability of five common weed species in competition with soybean. Int. J. Pest Manag. 63 30-36 (2017).

12. Pollnac, F. W., Maxwell, B. D. \& Menalled, F. D. Weed community characteristics and crop performance: a neighbourhood approach. Weed Res. 49, 242-250 (2009)

13. Davis, A. S., Renner, K. A. \& Gross, K. L. Weed seedbank and community shifts in a long-term cropping systems experiment. Weed Sci. 53, 296-306 (2005).

14. Clements, D. R., Weise, S. F. \& Swanton, C. J. Integrated weed management and weed species diversity. Phytoprotection 75, 1-18 (1994).

15. Aschehoug, E. T. \& Callaway, R. M. Diversity increases indirect interactions, attenuates the intensity of competition, and promotes coexistence. Am. Nat. 186, 452-459 (2015).

16. Weigelt, A. et al. Identifying mechanisms of competition in multi-species communities. J. Ecol. 95, 53-64 (2007).

17. Ali, A., Streibig, J. C. \& Andreasen, C. Yield loss prediction models based on early estimation of weed pressure. Crop Prot. 53, 125-131 (2013).

18. Freckleton, R. \& Watkinson, A. R. Asymmetric competition between plant species. Funct. Ecol. 15, 615-623 (2001).

19. Swinton, S. M., Buhler, D. D., Forcella, F., Gunsolus, J. L. \& King, R. P. Estimation of crop yield loss due to interference by multiple weed species. Weed Sci. 42, 103-109 (1994).

20. Poggio, S. L. \& Ghersa, C. M. Species richness and evenness as a function of biomass in arable plant communities. Weed Res. 51, 241-249 (2011).

21. Navas, M.-L. Trait-based approaches to unravelling the assembly of weed communities and their impact on agro-ecosystem functioning. Weed Res. 52, 479-488 (2012).
22. Bennett, J. A., Riibak, K., Tamme, R., Lewis, R. J. \& Pärtel, M. The reciprocal relationship between competition and intraspecific trait variation. J. Ecol. 104, 1410-1420 (2016)

23. Gibson, D. J., Young, B. G. \& Wood, A. J. Can weeds enhance profitability? Integrating ecological concepts to address crop-weed competition and yield quality. J. Ecol. 105, 900-904 (2017).

24. Cierjacks, A., Pommeranz, M., Schulz, K. \& Almeida-Cortez, J. Is crop yield related to weed species diversity and biomass in coconut and banana fields of northeastern Brazil? Agric. Ecosyst. Environ. 220, 175-183 (2016).

25. Ferrero, R., Lima, M., Davis, A. S. \& Gonzalez-Andujar, J. L. Weed diversity affects soybean and maize yield in a long term experiment in Michigan, USA. Front. Plant Sci. 8, 236 (2017)

26. Syswerda, S. P. \& Robertson, G. P. Ecosystem services along a management gradient in Michigan (USA) cropping systems. Agric. Ecosyst. Environ. 189, 28-35 (2014).

27. Mariotte, P. Do subordinate species punch above their weight? Evidence from above- and below-ground. New Phytol. 203, 16-21 (2014).

28. Wilson, B. \& Wright, K. Predicting the growth and competitive effects of annual weeds in wheat. Weed Res. 30, 201-211 (1990).

29. MacArthur, R. \& Levins, R. The limiting similarity, convergence, and divergence of coexisting species. Am. Nat. 101, 377-385 (1967).

30. Smith, R. G., Mortensen, D. A. \& Ryan, M. R. A new hypothesis for the functional role of diversity in mediating resource pools and weed-crop competition in agroecosystems. Weed Res. 50, 37-48 (2010).

31. Funk, J. L. \& Wolf, A. A. Testing the trait-based community framework: do functional traits predict competitive outcomes? Ecology $\mathbf{9 7}$, 2206-2211 (2016).

32. Satorre, E. H. \& Slafer, G. A. Wheat: Ecology and Physiology of Yield Determination (CRC Press, 1999).

33. Angonin, C., Caussanel, J. P. \& Meynard, J. M. Competition between winter wheat and Veronica hederifolia: influence of weed density and the amount and timing of nitrogen application. Weed Res. 36, 175-187 (1996).

34. Aschehoug, E. T., Brooker, R., Atwater, D. Z., Maron, J. L. \& Callaway, R. M. The mechanisms and consequences of interspecific competition among plants. Annu. Rev. Ecol. Evol. Syst. 47, 263-281 (2016).

35. Gherekhloo, J. et al. Multispecies weed competition and their economic threshold on the wheat crop. Planta Daninha 28, 239-246 (2010).

36. Zimdahl, R. L. Weed-Crop Competition: A Review (John Wiley \& Sons, 2007).

37. Welsh, J., Bulson, H., Stopes, C., Froud-Williams, R. \& Murdoch, A. The critical weed-free period in organically-grown winter wheat. Ann. Appl. Biol. 134, 315-320 (1999).

38. Bauer, G. et al. Always on the bright side: the climbing mechanism of Galium aparine. Proc. R. Soc. B 278, 2233-2239 (2010).

39. Magurran, A. E. \& McGill, B. J. (eds) Biological Diversity: Frontiers in Measurement and Assessment (Oxford Univ. Press, 2011).

40. Taylor, K. Galium aparine L. J. Ecol. 87, 713-730 (1999).

41. Storkey, J. \& Westbury, D. B. Managing arable weeds for biodiversity. Pest Manag. Sci. 63, 517-523 (2007).

42. Palmer, M. W. \& Maurer, T. A. Does diversity beget diversity? A case study of crops and weeds. J. Veg. Sci. 8, 235-240 (1997).

43. Booth, B. D. \& Swanton, C. J. Assembly theory applied to weed communities. Weed Sci. 50, 2-13 (2002).

44. Armengot, L., José-María, L., Chamorro, L. \& Sans, F. X. Avena sterilis and Lolium rigidum infestations hamper the recovery of diverse arable weed communities. Weed Res. 57, 278-286 (2017).

45. Adeux, G. et al. Diversified grain-based cropping systems provide long term weed control while limiting herbicide use and yield losses. Agron. Sustain. Dev. 39, 42 (2019).

46. Botta-Dukát, Z. Rao's quadratic entropy as a measure of functional diversity based on multiple traits. J. Veg. Sci. 16, 533-540 (2005).

47. Westoby, M. A leaf-height-seed (LHS) plant ecology strategy scheme. Plant Soil 199, 213-227 (1998).

48. Kleyer, M. et al. The LEDA Traitbase: a database of life-history traits of the Northwest European flora. J. Ecol. 96, 1266-1274 (2008).

49. R Core Team R: A Language and Environment for Statistical Computing (R Foundation for Statistical Computing, 2016).

\section{Acknowledgements}

We thank (1) P. Chamoy, B. Pouilly and P. Farcy of the INRA experimental station in Bretenière, France, who carried out this field experiment, (2) all who participated in field work (D. Meunier, G. Louviot, M. Abgrall, J. Degenmann and the team Grenier with A. Baudron, L. Grall, M. Schwartz and M. Angaud) and (3) N. Colbach and D. Moreau for their scientific input. G.A. was funded by the International PhD Programme in Agrobiodiversity of the Scuola Superiore Sant'Anna, Pisa, Italy, and hosted by the Institut National de la Recherche Agronomique in Dijon. We acknowledge financial support from the French project CoSAC (ANR-15-CE18-0007), the European Union's Horizon 2020 research and innovation programme under grant agreement no. 727321 (IWM PRAISE), the French 'Investissement d'Avenir' programme and the project ISITE-BFC 'Agroecology in BFC' (contract ANR-15-IDEX-03). 


\section{Author contributions}

N.M.-J. designed the study. N.M.-J., S.Cordeau and P.B. funded the research. G.A., E.V. and S.Cordeau collected the data. G.A. analysed the data. All authors were involved in the interpretation of the results and contributed to writing the original version of the manuscript and improving the subsequent ones.

\section{Competing interests}

The authors declare no competing interests.

\section{Additional information}

Supplementary information is available for this paper at https://doi.org/10.1038/ s41893-019-0415-y.

Correspondence and requests for materials should be addressed to S.C.

Reprints and permissions information is available at www.nature.com/reprints.

Publisher's note Springer Nature remains neutral with regard to jurisdictional claims in published maps and institutional affiliations.

(C) The Author(s), under exclusive licence to Springer Nature Limited 2019 
In the format provided by the authors and unedited.

\section{Mitigating crop yield losses through weed diversity}

Guillaume Adeux $\oplus^{1,2}$, Eric Vieren', Stefano Carlesi ${ }^{2}{ }^{2}$, Paolo Bàrberi ${ }^{2}$, Nicolas Munier-Jolain' and Stéphane Cordeau ${ }^{1 *}$

${ }^{1}$ Agroécologie, AgroSup Dijon, INRA, Univ. Bourgogne, Univ. Franche-Comté, Dijon, France. ${ }^{2}$ Group of Agroecology, Institute of Life Sciences, Scuola Superiore Sant'Anna, Pisa, Italy. *e-mail: stephane.cordeau@inra.fr 


\title{
Mitigating crop yield losses through weed diversity
}

\author{
Guillaume ADEUX ${ }^{1,2}$, Eric VIEREN ${ }^{1}$, Stefano CARLESI ${ }^{2}$, Paolo BARBERI ${ }^{2}$, Nicolas MUNIER-
} JOLAIN $^{1}$, Stéphane CORDEAU ${ }^{1 *}$

${ }^{1}$ Agroécologie; AgroSup Dijon; INRA; Univ. Bourgogne Franche-Comté; F-21000 Dijon; France

${ }^{2}$ Group of Agroecology; Institute of Life Sciences; Scuola Superiore Sant'Anna; Piazza Martiri della Libertà 33; 56127 Pisa; Italy

*Corresponding author: stephane.cordeau@inra.fr; Tel. +33 380693267

\section{Supplementary Methods}

\section{- Climatic conditions}

Average daily temperature from December to February was 5.5, 2.3 and $4.1^{\circ} \mathrm{C}$ during the $2015-16$, 2016-17 and 2017-18 growing seasons respectively. Average daily temperature from June to July was $19.5,20.8$ and $21.3^{\circ} \mathrm{C}$ during the $2015-16,2016-17$ and $2017-18$ growing seasons respectively. Total rainfall over the growing season of winter cereals was $630 \mathrm{~mm}$ in 2015-16, $397 \mathrm{~mm}$ in 2016-17 and $716 \mathrm{~mm}$ in $2017-18$, and its distribution varied across the three growing seasons (56\% of total rainfall from April to June 2016; 22\% of rainfall in November 2016 and 38\% over May and June 2017; 57\% of rainfall from December 2017 to March 2018).

\section{- Diversity measures based on density or biomass}

Initial density counts allowed us to investigate whether diversity indices based on early density counts could relate to weed biomass or crop productivity. The existence of such relationships would imply that early measures of weed diversity indices could be used as a practical monitoring tool for growers (at a moment when seedling's above ground biomass does not necessarily reflect its competitive ability later in the season). In NWC zones, this early scouting also allowed us to characterize weed communities before competition led to mortality and the evaluation of weed density was challenged by high biomass. However, authors have argued that biomass is more relevant to compute diversity indices $^{1,2}$. Therefore, initial weed density count allowed us to compare the explanatory power of weed diversity indices based on density and biomass.

\section{- Data analysis}

All regression analysis were carried out with the R software version $3.3 .2^{3}$ at the quadrat level. Generalised linear mixed effect models (GLMM) and linear mixed effect models (LMM) were performed in order to account for the nature of certain response variables and the hierarchical design of the experiment (zones nested in plots). GLMM were fitted with both packages lme4 (function glmer.nb) and glmmTMB (function glmmTMB) whereas LMM were fitted with the lme4 package only (function lmer, fitted by maximum likelihood in order to perform meaningful likelihood ratio tests). GLMM with a beta family and logit link function was used to model variables bounded between zero and one (i.e. evenness). When present, a small constant (i.e. 0.0001) was added to evenness values of zero (monospecific weed communities) and subtracted from evenness values of one (perfectly even communities). GLMM with a negative binomial family and log link function was used to model overdispersed counts (i.e. number of ears per plant). All other response variables were 
analysed with LMM and were either log or square root transformed to meet normality assumptions. Residuals were visualised with the DHARMa package and variance inflation factors were checked with the vif function of the car package.

Year was always treated as a fixed factor considering that three levels are not enough to estimate a random variance. Weed communities were always considered as factors. The interaction between crop stage and year was considered as random in the analysis of crop and weed biomass because it was not controlled by the experimenters (e.g. certain years, more weed or crop biomass was produced at elongation than other years). We are here focusing on the global trend across years while accounting for these year-to-year variations. 
A list of all the fitted models in R syntax (“*”" denotes main and interaction effects, “:” denotes interaction effects only, "(1|plot/zone)" denotes a random intercept for each zone nested in plot) and the data used to fit them can be found below:

\begin{tabular}{|c|c|c|c|c|}
\hline Number & Response & Explanatory variables & $\begin{array}{l}\text { Random } \\
\text { effects }\end{array}$ & Data used \\
\hline 0 & Weed density & Year + weed community & (1|plot/zone) & $\begin{array}{l}\text { All weedy quadrats from SWC } \\
\text { and NWC zones (only hand } \\
\text { weeded quadrats were not } \\
\text { considered) }\end{array}$ \\
\hline 1 & $\begin{array}{l}\text { Diversity indicators } \\
\text { (species richness, } \\
\text { Shannon diversity } \\
\text { index, evenness, Rao's } \\
\text { quadratic entropy) } \\
\text { based on density }\end{array}$ & Year + weed community & (1|plot/zone) & $\begin{array}{l}\text { All weedy quadrats from SWC } \\
\text { and NWC zones (only hand } \\
\text { weeded quadrats were not } \\
\text { considered) }\end{array}$ \\
\hline 2 & $\begin{array}{l}\text { Diversity variables } \\
\text { (species richness, } \\
\text { Shannon diversity } \\
\text { index, evenness, Rao's } \\
\text { quadratic entropy) } \\
\text { based on biomass }\end{array}$ & year + weed community $*$ crop stage & (1|plot/zone) & $\begin{array}{l}\text { All weedy quadrats from } \\
\text { NWC zones (hand weeded } \\
\text { quadrats from NWC zones } \\
\text { were not considered) }\end{array}$ \\
\hline 3 & Weed biomass & year + weed community $*$ crop stage & $\begin{array}{l}(1 \mid \text { plot/zone }) \\
+(1 \mid \text { crop } \\
\text { stage:year })\end{array}$ & $\begin{array}{l}\text { All weedy quadrats from } \\
\text { NWC zones (hand weeded } \\
\text { quadrats from NWC zones } \\
\text { were not considered) }\end{array}$ \\
\hline 4 & $\begin{array}{l}\text { Yield (not considering } \\
\text { weed communities) }\end{array}$ & $\begin{array}{l}\text { year }+ \text { crop density }+ \text { management type } \\
* \text { hand weeding }\end{array}$ & $(1 \mid$ plot/zone $)$ & $\begin{array}{l}\text { All quadrats sampled at crop } \\
\text { maturity (including hand } \\
\text { weeded quadrats) }\end{array}$ \\
\hline 5 & $\begin{array}{l}\text { Yield (considering } \\
\text { weed communities) }\end{array}$ & $\begin{array}{l}\text { year }+ \text { crop density }+ \text { management type } \\
* \text { hand weeding } * \text { weed community }\end{array}$ & $(1 \mid$ plot/zone $)$ & $\begin{array}{l}\text { All quadrats sampled at crop } \\
\text { maturity (including hand } \\
\text { weeded quadrats) }\end{array}$ \\
\hline 6 & $\begin{array}{l}\text { Number of ears per } \\
\text { plant }\end{array}$ & $\begin{array}{l}\text { year }+ \text { number of plants per } \mathrm{m}^{2}+ \\
\text { management type } * \text { hand weeding } * \\
\text { weed community }\end{array}$ & $(1 \mid$ plot/zone $)$ & $\begin{array}{l}\text { All quadrats sampled at crop } \\
\text { maturity (including hand } \\
\text { weeded quadrats) }\end{array}$ \\
\hline 7 & $\begin{array}{l}\text { Number of grains per } \\
\text { ear }\end{array}$ & $\begin{array}{l}\text { year }+ \text { number of ears per } \mathrm{m}^{2}+ \\
\text { management type } * \text { hand weeding } * \\
\text { weed community }\end{array}$ & (1|plot/zone) & $\begin{array}{l}\text { All quadrats sampled at crop } \\
\text { maturity (including hand } \\
\text { weeded quadrats) }\end{array}$ \\
\hline 8 & 1000-kernel weight & $\begin{array}{l}\text { year }+ \text { number of grains per } \mathrm{m}^{2+} \\
\text { management type } * \text { hand weeding } * \\
\text { weed community }\end{array}$ & (1|plot/zone) & $\begin{array}{l}\text { All quadrats sampled at crop } \\
\text { maturity (including hand } \\
\text { weeded quadrats) }\end{array}$ \\
\hline 9 & Crop biomass & $\begin{array}{l}\text { year }+ \text { crop density }+ \text { diversity * crop } \\
\text { stage } \\
\text { diversity: species richness, Shannon } \\
\text { diversity index, evenness, Rao's } \\
\text { quadratic entropy (either based on } \\
\text { density or biomass) }\end{array}$ & $\begin{array}{l}(1 \mid \text { plot/zone }) \\
+(1 \mid \text { crop } \\
\text { stage:year })\end{array}$ & $\begin{array}{l}\text { All weedy quadrats from } \\
\text { NWC zones (hand weeded } \\
\text { quadrats from NWC zones } \\
\text { were not considered) }\end{array}$ \\
\hline 10 & Weed biomass & $\begin{array}{l}\text { year }+ \text { crop density }+ \text { diversity } * \text { crop } \\
\text { stage } \\
\text { diversity: species richness, Shannon } \\
\text { diversity index, evenness, Rao's } \\
\text { quadratic entropy (either based on } \\
\text { density or biomass) }\end{array}$ & $\begin{array}{l}(1 \mid \text { plot/zone }) \\
+(1 \mid \text { crop } \\
\text { stage:year })\end{array}$ & $\begin{array}{l}\text { All weedy quadrats from } \\
\text { NWC zones (hand weeded } \\
\text { quadrats from NWC zones } \\
\text { were not considered) }\end{array}$ \\
\hline 11 & Crop biomass & $\begin{array}{l}\text { year }+ \text { crop density }+ \text { weed } \\
\text { biomass } * \text { crop stage }\end{array}$ & $\begin{array}{l}(1 \mid \text { plot/zone }) \\
+(1 \mid \text { crop } \\
\text { stage:year })\end{array}$ & $\begin{array}{l}\text { All weedy quadrats from } \\
\text { NWC zones (hand weeded } \\
\text { quadrats from NWC zones } \\
\text { were not considered) }\end{array}$ \\
\hline 12 & $\begin{array}{l}\text { Diversity indicators } \\
\text { (based on biomass) }\end{array}$ & $\begin{array}{l}\text { year }+ \text { diversity (based on } \\
\text { density)* crop stage }\end{array}$ & (1|plot/zone) & $\begin{array}{l}\text { All weedy quadrats from } \\
\text { NWC zones (hand weeded } \\
\text { quadrats from NWC zones } \\
\text { were not considered) }\end{array}$ \\
\hline
\end{tabular}


For the analysis of yield components, the integration of a different covariate for each yield component allowed us to distinguish (i) the compensation effects between earlier (and potentially affected) yield components and the yield component of interest from (ii) the effect of competition on the yield component of interest.

Crop density (when included, as continuous) and year were always considered as a priori covariates and were never removed from the models. However, the interaction was removed when not significant for the last four sets of predictive models (models 9-12) to reach parsimony and to avoid graphically representing non significantly different slopes. Significance of effects was assessed by type III F-tests for LMM or by type III Wald chi-square tests for GLMM. All contrasts for multiple comparison were set up using the emmeans package. Finally, coefficient of determination $\left(\mathrm{R}^{2}\right)$ was computed when possible using the function r.squaredGLMM of the MuMIn package. For GLMM or LMM, $\mathrm{R}^{2}$ is partitioned into a marginal $\mathrm{R}^{2}\left(\mathrm{R}^{2} \mathrm{~m}\right)$, which is the variance explained by the fixed factors, and a conditional $\mathrm{R}^{2}\left(\mathrm{R}^{2} \mathrm{c}\right)$, which is the variance explained by both fixed and random factors (i.e., the entire model $)^{4}$. 


\section{Supplementary Tables}

Supplementary Table 1: Type III A) analysis of deviance table analysis (Type III Wald chi-square tests) and B) analysis of variance table with Satterthwaite's method showing the effect of the tested explanatory variables on grains yields (considering weed community clusters (WCC) or not), number of ears per plant, number of grains per ear and 1000-kernel weight. $R^{2}$ is partitioned into marginal $R^{2}\left(R^{2} m\right)$; the variance explained by the fixed factors and conditional $R^{2}\left(R^{2} c\right)$; the variance explained by both fixed and random factors (i.e. the entire model). Num: numerator; Den: denominator; df: degrees of freedom; $t: \log$ transformed. Significant $(\mathrm{p} \leq 0.05)$ values are highlighted in bold.

a)

\begin{tabular}{|l|l|c|c|c|}
\hline Response variable & Explanatory variables & Chi-sq & df & p.value \\
\hline \multirow{5}{*}{ Number of ears per plant } & Year & 20.4433 & 1 & $<\mathbf{0 . 0 0 0 1}$ \\
\cline { 2 - 5 } & Wheat density per $\mathrm{m}^{2}$ & 34.6529 & 1 & $<\mathbf{0 . 0 0 0 1}$ \\
\cline { 2 - 5 } & Management type & 13.0677 & 1 & $\mathbf{0 . 0 0 0 3}$ \\
\cline { 2 - 5 } & WCC & 20.0030 & 5 & $\mathbf{0 . 0 0 1}$ \\
\cline { 2 - 5 } & Hand weeding & 12.5864 & 1 & $\mathbf{0 . 0 0 0 4}$ \\
\cline { 2 - 5 } & Management type $\times$ WCC & 10.3059 & 3 & $\mathbf{0 . 0 2}$ \\
\cline { 2 - 5 } & Management type x Hand weeding & 6.6795 & 1 & $\mathbf{0 . 0 1}$ \\
\cline { 2 - 5 } & WCC x Hand weeding & 29.2599 & 5 & $<\mathbf{0 . 0 0 0 1}$ \\
\cline { 2 - 5 } & Management type $\times$ WCC x Hand weeding & 4.0562 & 3 & 0.26 \\
\hline
\end{tabular}




\begin{tabular}{|c|c|c|c|c|c|c|c|c|c|}
\hline Response variable & Explanatory variables & Sum of squares & Mean Square & Num. df & Den. $\mathrm{df}$ & F-value & p.value & $R^{2}(m)$ & $R^{2}(c)$ \\
\hline \multirow{2}{*}{$\begin{array}{l}\text { Grain yields } \\
\text { (without WCC) }\end{array}$} & Management type & 0.96116 & 0.96116 & 1 & 47.345 & 19.1634 & $<0.0001$ & \multirow[t]{2}{*}{0.68} & \multirow[t]{2}{*}{0.69} \\
\hline & Hand weeding & 0.68721 & 0.68721 & 1 & 53.741 & 13.7015 & 0.0005 & & \\
\hline \multirow{7}{*}{$\begin{array}{l}\text { Grain yields } \\
\text { (with WCC) }\end{array}$} & Year & 0.95810 & 0.47905 & 2 & 58.341 & 21.5020 & $<0.0001$ & \multirow{7}{*}{0.85} & \multirow{7}{*}{0.86} \\
\hline & Wheat density & 0.33760 & 0.33760 & 1 & 69.871 & 15.1529 & 0.0002 & & \\
\hline & Management type & 0.71639 & 0.71639 & 1 & 53.680 & 32.1553 & $<0.0001$ & & \\
\hline & Management type x WCC & 0.53621 & 0.17874 & 3 & 53.869 & 8.0226 & 0.0002 & & \\
\hline & Management type $x$ Hand weeding & 0.35114 & 0.35114 & 1 & 53.706 & 15.7608 & 0.0002 & & \\
\hline & WCC $x$ Hand weeding & 0.94466 & 0.18893 & 5 & 53.651 & 8.4802 & $<0.0001$ & & \\
\hline & Management type $\times$ WCC $\times$ Hand weeding & 0.14773 & 0.04924 & 3 & 53.740 & 2.2103 & 0.10 & & \\
\hline \multirow{4}{*}{$\begin{array}{l}\text { Number of grains } \\
\text { per ear }\end{array}$} & Year & 0.280860 & 0.140430 & 2 & 4.983 & 17.8105 & 0.005 & \multirow{4}{*}{0.67} & \multirow{4}{*}{0.79} \\
\hline & Number of ears per $\mathrm{m}^{2}$ & 0.105797 & 0.105797 & 1 & 97.918 & 13.4180 & 0.0004 & & \\
\hline & Management type & 0.019059 & 0.019059 & 1 & 52.797 & 2.4172 & 0.13 & & \\
\hline & Management type $\times$ WCC $\times$ Hand weeding & 0.012477 & 0.004159 & 3 & 53.784 & 0.5275 & 0.66 & & \\
\hline \multirow{9}{*}{$\begin{array}{l}\text { 1000-kernel } \\
\text { weight }\end{array}$} & Year & 0.076565 & 0.038282 & 2 & 7.446 & 15.8971 & 0.002 & \multirow{9}{*}{0.65} & \multirow{9}{*}{0.86} \\
\hline & Number of grains per $\mathrm{m}^{2}$ & 0.001668 & 0.001668 & 1 & 94.643 & 0.6926 & 0.41 & & \\
\hline & Management type & 0.002188 & 0.002188 & 1 & 52.667 & 0.9087 & 0.34 & & \\
\hline & WCC & 0.009461 & 0.001892 & 5 & 44.794 & 0.7858 & 0.56 & & \\
\hline & Hand weeding & 0.000049 & 0.000049 & 1 & 63.216 & 0.0203 & 0.89 & & \\
\hline & Management type $\mathrm{x}$ WCC & 0.004683 & 0.001561 & 3 & 47.534 & 0.6483 & 0.59 & & \\
\hline & Management type $x$ Hand weeding & 0.013108 & 0.013108 & 1 & 56.436 & 5.4432 & 0.02 & & \\
\hline & WCC $x$ Hand weeding & 0.028988 & 0.005798 & 5 & 54.902 & 2.4075 & 0.05 & & \\
\hline & Management type $\times$ WCC $\times$ Hand weeding & 0.024572 & 0.008191 & 3 & 53.591 & 3.4012 & 0.02 & & \\
\hline
\end{tabular}


Supplementary Table 2: Type III a) analysis of variance table with Satterthwaite's method or b) Analysis of deviance table (Type III Wald chisquare tests) showing the effect of weed community clusters (WCC) on weed density, species richness, Shannon diversity index, Rao's quadratic entropy and evenness (the four latter computed on initial density data) across both No Weed Control (NWC) and Standard Weed Control (SWC) zones. $\mathrm{R}^{2}$ is partitioned into marginal $\mathrm{R}^{2}$ $\left(\mathrm{R}^{2} \mathrm{~m}\right)$; the variance explained by the fixed factors and conditional $\mathrm{R}^{2}\left(\mathrm{R}^{2} \mathrm{c}\right)$; the variance explained by both fixed and random factors (i.e. the entire model). Num: numerator; Den: denominator; df: degrees of freedom; $\neq: \log$ transformed; *: square root transformed. Significant $(\mathrm{p} \leq 0.05)$ values are highlighted in bold.

a)

\begin{tabular}{|c|c|c|c|c|c|c|c|c|c|}
\hline Response variables & Explanatory variables & Sum of squares & Mean square & Num. df & Den. df & F-value & p.value & $R^{2}(m)$ & $R^{2}(c)$ \\
\hline \multirow{2}{*}{ Weed density ${ }^{\ddagger}$} & Year & 1.2870 & 0.64352 & 2 & 5.554 & 4.1711 & 0.08 & \multirow{2}{*}{0.59} & \multirow{2}{*}{0.83} \\
\hline & WCC & 5.7095 & 1.14189 & 5 & 51.632 & 7.4014 & $<0.0001$ & & \\
\hline \multirow{2}{*}{ Species richness ${ }^{\ddagger}$} & Year & 0.85657 & 0.42829 & 2 & 3.301 & 6.7214 & 0.07 & \multirow{2}{*}{0.39} & \multirow{2}{*}{0.70} \\
\hline & WCC & 0.56174 & 0.11235 & 5 & 49.621 & 1.7631 & 0.14 & & \\
\hline \multirow{2}{*}{ Shannon diversity index* } & Year & 0.14746 & 0.073732 & 2 & 4.154 & 3.3076 & 0.14 & \multirow{2}{*}{0.37} & \multirow{2}{*}{0.73} \\
\hline & WCC & 0.73993 & 0.147986 & 5 & 47.469 & 6.6385 & $<0.0001$ & & \\
\hline \multirow{2}{*}{ Rao's quadratic entropy* } & Year & 0.0944 & 0.04720 & 2 & 4.966 & 0.3326 & 0.73 & \multirow{2}{*}{0.25} & \multirow{2}{*}{0.64} \\
\hline & WCC & 3.8421 & 0.76843 & 5 & 37.287 & 5.4146 & 0.0008 & & \\
\hline
\end{tabular}

b)

\begin{tabular}{|l|l|c|c|c|}
\hline Response variable & Explanatory variables & Chi-sq & df & p.value \\
\hline \multirow{2}{*}{ Evenness } & Year & 1.6394 & 1 & 0.44 \\
\cline { 2 - 5 } & WCC & 21.2625 & 5 & $\mathbf{0 . 0 0 0 7}$ \\
\hline
\end{tabular}


Supplementary Table 3: Type III a) analysis of variance table with Satterthwaite's method or b) analysis of deviance table (Wald chisquare tests) showing the effect of weed community clusters (WCC) and crop stage on weed biomass, species richness, Shannon diversity index, Rao's quadratic entropy and evenness (the four latter computed on biomass data). Only No Weed Control (NWC) zones were considered. $\mathrm{R}^{2}$ is partitioned into marginal $\mathrm{R}^{2}\left(\mathrm{R}^{2} \mathrm{~m}\right.$ ); the variance explained by the fixed factors and conditional $\mathrm{R}^{2}\left(\mathrm{R}^{2} \mathrm{c}\right)$; the variance explained by both fixed and random factors (i.e. the entire model). Num: numerator; Den: denominator; df: degrees of freedom; $\ddagger$ : $\log$ transformed; *: square root transformed. Significant $(\mathrm{p} \leq 0.05)$ values are highlighted in bold.

a)

\begin{tabular}{|c|c|c|c|c|c|c|c|c|c|}
\hline Response variables & Explanatory variables & Sum of squares & Mean square & Num. df & Den. df & F-value & p.value & $R^{2}(m)$ & $R^{2}(c)$ \\
\hline \multirow{4}{*}{ Weed biomass } & Year & 0.5993 & 0.29964 & 2 & 6.659 & 1.6622 & 0.26 & \multirow{4}{*}{0.51} & \multirow{4}{*}{0.86} \\
\hline & WCC & 5.7029 & 1.14059 & 5 & 29.568 & 6.3273 & 0.0004 & & \\
\hline & Crop stage & 5.9075 & 1.96918 & 3 & 5.263 & 10.9238 & 0.01 & & \\
\hline & WCC $\times$ Crop stage & 6.0436 & 0.40291 & 15 & 92.883 & 2.2351 & 0.01 & & \\
\hline \multirow{4}{*}{ Species richness ${ }^{\ddagger}$} & Year & 12.4690 & 6.2345 & 2 & 35 & 90.3837 & $<0.0001$ & \multirow{4}{*}{0.75} & \multirow{4}{*}{0.77} \\
\hline & WCC & 3.0130 & 0.6026 & 5 & 35 & 8.7362 & $<0.0001$ & & \\
\hline & Crop stage & 2.5764 & 0.8588 & 3 & 105 & 12.4505 & $<0.0001$ & & \\
\hline & WCC $\times$ Crop stage & 2.8191 & 0.1879 & 15 & 105 & 2.7246 & 0.001 & & \\
\hline \multirow{4}{*}{ Shannon Diversity Index* } & Year & 0.37871 & 0.18936 & 2 & 35 & 7.6787 & 0.002 & \multirow{4}{*}{0.58} & \multirow{4}{*}{0.72} \\
\hline & WCC & 2.07478 & 0.41496 & 5 & 35 & 16.8273 & $<0.0001$ & & \\
\hline & Crop stage & 0.06949 & 0.02316 & 3 & 105 & 0.9393 & 0.42 & & \\
\hline & WCC $\times$ Crop stage & 0.30499 & 0.02033 & 15 & 105 & 0.8245 & 0.65 & & \\
\hline \multirow{4}{*}{ Rao's quadratic entropy* } & Year & 0.5889 & 0.29444 & 2 & 35 & 2.5718 & 0.09 & \multirow{4}{*}{0.47} & \multirow{4}{*}{0.71} \\
\hline & WCC & 5.1929 & 1.03857 & 5 & 35 & 9.0715 & $<0.0001$ & & \\
\hline & Crop stage & 0.3017 & 0.10057 & 3 & 105 & 0.8785 & 0.45 & & \\
\hline & WCC $\times$ Crop stage & 2.4605 & 0.16404 & 15 & 105 & 1.4328 & 0.15 & & \\
\hline
\end{tabular}

b)

\begin{tabular}{|l|l|c|c|c|}
\hline Response variable & Explanatory variables & Chi-sq & df & p.value \\
\hline \multirow{4}{*}{ Evenness } & Year & 1.7019 & 1 & 0.43 \\
\cline { 2 - 5 } & WCC & 16.7769 & 5 & $\mathbf{0 . 0 0 5}$ \\
\cline { 2 - 5 } & Crop stage & 2.0759 & 3 & 0.56 \\
\cline { 2 - 5 } & WCC $x$ Crop stage & 8.4706 & 15 & 0.90 \\
\hline
\end{tabular}


Supplementary Table 4: Type III analysis of variance table with Satterthwaite's method highlighting the effect of the different diversity variables based on density data (species richness, Shannon diversity index, Evenness and Rao's quadratic entropy) on crop productivity. Only No Weed Control (NWC) zones were considered. $\mathrm{R}^{2}$ is partitioned into marginal $R^{2}\left(R^{2} m\right)$; the variance explained by the fixed factors and conditional $R^{2}\left(R^{2} c\right)$; the variance explained by both fixed and random factors (i.e. the entire model). Num: numerator; Den: denominator; df: degrees of freedom; ; log transformed. Significant $(\mathrm{p} \leq 0.05)$ values are highlighted in bold.

\begin{tabular}{|c|c|c|c|c|c|c|c|c|c|}
\hline Response variables & Explanatory variables & Sum of squares & Mean square & Num. df & Den. $d f$ & F-value & p.value & $R^{2}(m)$ & $\mathrm{R}^{2}(\mathrm{c})$ \\
\hline \multirow{5}{*}{ Crop biomass* } & Year & 0.46629 & 0.23315 & 2 & 11.428 & 7.8654 & 0.007 & \multirow{5}{*}{0.81} & \multirow{5}{*}{0.93} \\
\hline & Wheat density & 0.59646 & 0.59646 & 1 & 127.706 & 20.1221 & $<0.0001$ & & \\
\hline & Species richness & 0.00546 & 0.00546 & 1 & 100.361 & 0.1844 & 0.67 & & \\
\hline & Crop stage & 2.52809 & 0.84270 & 3 & 9.127 & 28.4289 & $<0.0001$ & & \\
\hline & Species richness $x$ Crop stage & 0.00694 & 0.00231 & 3 & 109.943 & 0.0780 & 0.97 & & \\
\hline \multirow{5}{*}{ Crop biomass: } & Year & 0.75474 & 0.37737 & 2 & 11.527 & 12.6405 & 0.001 & \multirow{5}{*}{0.83} & \multirow{5}{*}{0.93} \\
\hline & Wheat density & 0.60437 & 0.60437 & 1 & 121.637 & 20.2440 & $<0.0001$ & & \\
\hline & Shannon diversity index & 0.12971 & 0.12971 & 1 & 93.857 & 4.3447 & 0.04 & & \\
\hline & Crop stage & 2.92714 & 0.97571 & 3 & 10.218 & 32.6827 & $<0.0001$ & & \\
\hline & Shannon diversity index $x$ Crop stage & 0.10515 & 0.03505 & 3 & 100.073 & 1.1740 & 0.32 & & \\
\hline \multirow{5}{*}{ Crop biomass: } & Year & 0.65969 & 0.32985 & 2 & 11.941 & 11.3243 & 0.002 & \multirow{5}{*}{0.83} & \multirow{5}{*}{0.93} \\
\hline & Wheat density & 0.57778 & 0.57778 & 1 & 118.050 & 19.8365 & $<0.0001$ & & \\
\hline & Evenness & 0.19450 & 0.19450 & 1 & 116.053 & 6.6774 & 0.01 & & \\
\hline & Crop stage & 2.51081 & 0.83694 & 3 & 11.021 & 28.7336 & $<0.0001$ & & \\
\hline & Evenness $x$ Crop stage & 0.12409 & 0.04136 & 3 & 98.452 & 1.4201 & 0.24 & & \\
\hline \multirow{5}{*}{ Crop biomass* } & Year & 0.55124 & 0.27562 & 2 & 11.426 & 9.3166 & 0.004 & \multirow{5}{*}{0.82} & \multirow{5}{*}{0.92} \\
\hline & Wheat density & 0.65089 & 0.65089 & 1 & 124.098 & 22.0020 & $<0.0001$ & & \\
\hline & Rao's quadratic entropy & 0.05050 & 0.05050 & 1 & 95.296 & 1.7070 & 0.19 & & \\
\hline & Crop stage & 2.47140 & 0.82380 & 3 & 10.759 & 27.8466 & $<0.0001$ & & \\
\hline & Rao's quadratic entropy $x$ Crop stage & 0.09744 & 0.03248 & 3 & 96.944 & 1.0980 & 0.35 & & \\
\hline
\end{tabular}


Supplementary Table 5: Type III analysis of variance table with Satterthwaite's method highlighting the effect of weed biomass and different diversity variables based on biomass data (species richness, Shannon diversity index, Evenness and Rao's quadratic entropy) on crop productivity. Only No Weed Control (NWC) zones were considered. $\mathrm{R}^{2}$ is partitioned into marginal $\mathrm{R}^{2}\left(\mathrm{R}^{2} \mathrm{~m}\right)$; the variance explained by the fixed factors and conditional $\mathrm{R}^{2}\left(\mathrm{R}^{2} \mathrm{c}\right)$; the variance explained by both fixed and random factors (i.e. the entire model). Num: numerator; Den: denominator; df: degrees of freedom; $\neq$ : log transformed. Significant ( $\mathrm{p} \leq 0.05$ ) values are highlighted in bold.

\begin{tabular}{|c|c|c|c|c|c|c|c|c|c|}
\hline Response variables & Explanatory variables & Sum of squares & Mean square & Num. df & Den. df & F-value & p.value & $R^{2}(m)$ & $R^{2}(c)$ \\
\hline \multirow{5}{*}{ Crop biomass } & Year & 0.50562 & 0.25281 & 2 & 16.848 & 10.6089 & 0.001 & \multirow{5}{*}{0.84} & \multirow{5}{*}{0.94} \\
\hline & Wheat density & 0.71148 & 0.71148 & 1 & 101.589 & 29.8568 & $<0.0001$ & & \\
\hline & Weed biomass & 0.55112 & 0.55112 & 1 & 52.306 & 23.1272 & $<0.0001$ & & \\
\hline & Crop stage & 1.62253 & 0.54084 & 3 & 12.966 & 22.6960 & $<0.0001$ & & \\
\hline & Weed biomass $x$ Crop stage & 0.17831 & 0.05944 & 3 & 109.082 & 2.4942 & 0.06 & & \\
\hline \multirow{5}{*}{ Crop biomass } & Year & 0.61832 & 0.30916 & 2 & 11.726 & 11.0380 & 0.002 & \multirow{5}{*}{0.82} & \multirow{5}{*}{0.94} \\
\hline & Wheat density & 0.42322 & 0.42322 & 1 & 125.686 & 15.1103 & 0.0002 & & \\
\hline & Species richness & 0.06017 & 0.06017 & 1 & 122.133 & 2.1483 & 0.14 & & \\
\hline & Crop stage & 2.47942 & 0.82647 & 3 & 8.712 & 29.5080 & $<0.0001$ & & \\
\hline & Species richness $x$ Crop stage & 0.17830 & 0.05943 & 3 & 111.147 & 2.1220 & 0.10 & & \\
\hline \multirow{5}{*}{ Crop biomass } & Year & 0.65376 & 0.32688 & 2 & 11.492 & 11.5019 & 0.002 & \multirow{5}{*}{0.83} & \multirow{5}{*}{0.93} \\
\hline & Wheat density & 0.62511 & 0.62511 & 1 & 122.529 & 21.9960 & $<0.0001$ & & \\
\hline & Shannon diversity index & 0.13123 & 0.13123 & 1 & 122.043 & 4.6177 & 0.03 & & \\
\hline & Crop stage & 2.56089 & 0.85363 & 3 & 10.838 & 30.0369 & $<0.0001$ & & \\
\hline & Shannon diversity index x Crop stage & 0.20590 & 0.06863 & 3 & 99.819 & 2.4150 & 0.07 & & \\
\hline \multirow{5}{*}{ Crop biomass } & Year & 0.56526 & 0.28263 & 2 & 11.801 & 10.0421 & 0.003 & \multirow{5}{*}{0.83} & \multirow{5}{*}{0.93} \\
\hline & Wheat density & 0.69442 & 0.69442 & 1 & 123.212 & 24.6735 & $<0.0001$ & & \\
\hline & Evenness & 0.13978 & 0.13978 & 1 & 127.473 & 4.9667 & 0.03 & & \\
\hline & Crop stage & 2.36489 & 0.78830 & 3 & 10.857 & 28.0090 & $<0.0001$ & & \\
\hline & Evenness $\mathrm{x}$ Crop stage & 0.21365 & 0.07122 & 3 & 100.563 & 2.5304 & 0.06 & & \\
\hline \multirow{5}{*}{ Crop biomass* } & Year & 0.56191 & 0.28095 & 2 & 11.722 & 9.7966 & 0.003 & \multirow{5}{*}{0.82} & \multirow{5}{*}{0.93} \\
\hline & Wheat density & 0.59691 & 0.59691 & 1 & 123.788 & 20.8136 & $<0.0001$ & & \\
\hline & Rao's quadratic entropy & 0.15125 & 0.15125 & 1 & 122.210 & 5.2741 & 0.02 & & \\
\hline & Crop stage & 2.33702 & 0.77901 & 3 & 10.891 & 27.1633 & $<0.0001$ & & \\
\hline & Rao's quadratic entropy x Crop stage & 0.17184 & 0.05728 & 3 & 102.569 & 1.9973 & 0.12 & & \\
\hline
\end{tabular}


Supplementary Table 6: Type III analysis of variance table with Satterthwaite's method highlighting the effect of different diversity variables based on density data (species richness, Shannon diversity index, Evenness and Rao's quadratic entropy) on weed biomass. Only No Weed Control (NWC) zones were considered. $R^{2}$ is partitioned into marginal $R^{2}\left(R^{2} m\right)$; the variance explained by the fixed factors and conditional $R^{2}\left(R^{2} c\right)$; the variance explained by both fixed and random factors (i.e. the entire model). Num: numerator; Den: denominator; df: degrees of freedom; $\$$ : $\log$ transformed. Significant $(\mathrm{p} \leq 0.05)$ values are highlighted in bold.

\begin{tabular}{|c|c|c|c|c|c|c|c|c|c|}
\hline Response variables & Explanatory variables & Sum of squares & Mean square & Num. df & Den. $d f$ & F-value & p.value & $R^{2}(m)$ & $R^{2}(c)$ \\
\hline \multirow{5}{*}{ Weed biomass } & Year & 0.3626 & 0.18128 & 2 & 6.813 & 0.7605 & 0.50 & \multirow{5}{*}{0.34} & \multirow{5}{*}{0.84} \\
\hline & Wheat density & 0.6905 & 0.69049 & 1 & 126.156 & 2.8968 & 0.09 & & \\
\hline & Species richness & 0.0025 & 0.00247 & 1 & 95.324 & 0.0104 & 0.92 & & \\
\hline & Crop stage & 8.1060 & 2.70199 & 3 & 6.579 & 11.3357 & 0.005 & & \\
\hline & Species richness $x$ Crop stage & 0.3390 & 0.11299 & 3 & 75.851 & 0.4740 & 0.70 & & \\
\hline \multirow{5}{*}{ Weed biomass ${ }^{*}$} & Year & 0.4131 & 0.20656 & 2 & 6.804 & 0.9056 & 0.45 & \multirow{5}{*}{0.35} & \multirow{5}{*}{0.85} \\
\hline & Wheat density & 0.5380 & 0.53796 & 1 & 128.333 & 2.3585 & 0.13 & & \\
\hline & Shannon diversity index & 0.1690 & 0.16902 & 1 & 108.805 & 0.7410 & 0.39 & & \\
\hline & Crop stage & 5.9447 & 1.98157 & 3 & 8.512 & 8.6873 & 0.006 & & \\
\hline & Shannon diversity index $x$ Crop stage & 0.7682 & 0.25608 & 3 & 107.819 & 1.1227 & 0.34 & & \\
\hline \multirow{5}{*}{ Weed biomass } & Year & 0.4233 & 0.21163 & 2 & 6.535 & 0.9094 & 0.45 & \multirow{5}{*}{0.36} & \multirow{5}{*}{0.84} \\
\hline & Wheat density & 0.4578 & 0.45778 & 1 & 131.095 & 1.9673 & 0.16 & & \\
\hline & Evenness & 0.3107 & 0.31070 & 1 & 128.371 & 1.3352 & 0.25 & & \\
\hline & Crop stage & 7.1144 & 2.37147 & 3 & 9.551 & 10.1912 & 0.002 & & \\
\hline & Evenness $x$ Crop stage & 0.5809 & 0.19363 & 3 & 104.836 & 0.8321 & 0.48 & & \\
\hline \multirow{5}{*}{ Weed biomass } & Year & 0.2536 & 0.12682 & 2 & 6.464 & 0.5316 & 0.61 & \multirow{5}{*}{0.33} & \multirow{5}{*}{0.86} \\
\hline & Wheat density & 1.2311 & 1.23111 & 1 & 120.853 & 5.1603 & 0.02 & & \\
\hline & Rao's quadratic entropy & 0.9158 & 0.91579 & 1 & 90.072 & 3.8386 & 0.05 & & \\
\hline & Crop stage & 7.3000 & 2.43334 & 3 & 9.344 & 10.1996 & 0.003 & & \\
\hline & Rao's quadratic entropy $x$ Crop stage & 0.2613 & 0.08710 & 3 & 103.847 & 0.3651 & 0.78 & & \\
\hline
\end{tabular}


Supplementary Table 7: Type III analysis of variance table with Satterthwaite's method highlighting the effect of different diversity variables based on biomass data (species richness, Shannon diversity index, Evenness and Rao's quadratic entropy) on weed biomass. Only No Weed Control (NWC) zones were considered. $\mathrm{R}^{2}$ is partitioned into marginal $\mathrm{R}^{2}\left(\mathrm{R}^{2} \mathrm{~m}\right)$; the variance explained by the fixed factors and conditional $\mathrm{R}^{2}\left(\mathrm{R}^{2} \mathrm{c}\right)$; the variance explained by both fixed and random factors (i.e. the entire model). Num: numerator; Den: denominator; df: degrees of freedom; $\$$ : log transformed. Significant ( $\leq 0.05$ ) values are highlighted in bold.

\begin{tabular}{|c|c|c|c|c|c|c|c|c|c|}
\hline Response variables & Explanatory variables & Sum of squares & Mean square & Num. df & Den. df & F-value & p.value & $\mathrm{R}^{2}(\mathrm{~m})$ & $\mathrm{R}^{2}(\mathrm{c})$ \\
\hline \multirow{5}{*}{ Weed biomass $*$} & Year & 0.3188 & 0.1594 & 2 & 6.43 & 0.6718 & 0.54 & \multirow{5}{*}{0.35} & \multirow{5}{*}{0.85} \\
\hline & Wheat density & 0.8080 & 0.8080 & 1 & 132.97 & 3.4059 & 0.07 & & \\
\hline & Species richness & 0.0821 & 0.0821 & 1 & 129.94 & 0.3462 & 0.56 & & \\
\hline & Crop stage & 19.7127 & 6.5709 & 3 & 107.11 & 27.6992 & $<0.0001$ & & \\
\hline & Species richness $x$ Crop stage & 4.2103 & 1.4034 & 3 & 110.72 & 5.9160 & 0.0009 & & \\
\hline \multirow{5}{*}{ Weed biomass } & Year & 0.5482 & 0.27408 & 2 & 6.789 & 1.2472 & 0.35 & \multirow{5}{*}{0.41} & \multirow{5}{*}{0.84} \\
\hline & Wheat density & 0.4208 & 0.42078 & 1 & 122.159 & 1.9147 & 0.17 & & \\
\hline & Shannon diversity index & 2.8932 & 2.89317 & 1 & 117.201 & 13.1650 & 0.0004 & & \\
\hline & Crop stage & 6.0957 & 2.03189 & 3 & 9.449 & 9.2458 & 0.004 & & \\
\hline & Shannon diversity index $x$ Crop stage & 1.5817 & 0.52723 & 3 & 105.937 & 2.3991 & 0.07 & & \\
\hline \multirow{5}{*}{ Weed biomass* } & Year & 0.4859 & 0.2429 & 2 & 6.675 & 1.2266 & 0.35 & \multirow{5}{*}{0.47} & \multirow{5}{*}{0.85} \\
\hline & Wheat density & 0.5105 & 0.5105 & 1 & 123.943 & 2.5778 & 0.11 & & \\
\hline & Evenness & 5.0363 & 5.0363 & 1 & 129.977 & 25.4304 & $<0.0001$ & & \\
\hline & Crop stage & 7.4159 & 2.4720 & 3 & 9.308 & 12.4820 & 0.001 & & \\
\hline & Evenness x Crop stage & 2.9372 & 0.9791 & 3 & 106.340 & 4.9436 & 0.003 & & \\
\hline \multirow{5}{*}{ Weed biomass* } & Year & 0.3555 & 0.17775 & 2 & 6.499 & 0.7611 & 0.50 & \multirow{5}{*}{0.34} & \multirow{5}{*}{0.85} \\
\hline & Wheat density & 0.6970 & 0.69700 & 1 & 131.235 & 2.9845 & 0.09 & & \\
\hline & Rao's quadratic entropy & 0.0805 & 0.08053 & 1 & 123.723 & 0.3448 & 0.56 & & \\
\hline & Crop stage & 7.8781 & 2.62602 & 3 & 9.533 & 11.2445 & 0.002 & & \\
\hline & Rao's quadratic entropy x Crop stage & 0.6978 & 0.23261 & 3 & 105.930 & 0.9960 & 0.40 & & \\
\hline
\end{tabular}


Supplementary Table 8: Type III a) analysis of variance table with Satterthwaite's method or b) analysis of deviance table ((Wald chisquare tests) highlighting the relationship between different diversity variables (species richness, Shannon diversity index, Rao's quadratic entropy and evenness) computed on initial density data and their reciprocal computed on biomass data at four different crop stages. Only No Weed Control (NWC) zones were considered. $\mathrm{R}^{2}$ is partitioned into marginal $R^{2}\left(R^{2} m\right)$; the variance explained by the fixed factors and conditional $R^{2}\left(R^{2} c\right)$; the variance explained by both fixed and random factors (i.e. the entire model). Num: numerator; Den: denominator; df: degrees of freedom; $\ddagger$ : $\log$ transformed; *: square root transformed. Significant ( $\leq 0.05)$ values are highlighted in bold.

a)

\begin{tabular}{|c|c|c|c|c|c|c|c|c|c|}
\hline Response variables & Explanatory variables & Sum of squares & Mean square & Num. df & Den. $d f$ & F-value & p.value & $R^{2}(m)$ & $R^{2}(c)$ \\
\hline \multirow{4}{*}{ Species richness } & Year & 2.10461 & 1.05230 & 2 & 3.192 & 10.5404 & 0.04 & \multirow{4}{*}{0.58} & \multirow{4}{*}{0.69} \\
\hline & Species richness & 0.66485 & 0.66485 & 1 & 76.201 & 6.6595 & 0.01 & & \\
\hline & Crop stage & 2.74153 & 0.91384 & 3 & 97.768 & 9.1535 & $<0.0001$ & & \\
\hline & Species richness $x$ Crop stage & 0.25047 & 0.082349 & 3 & 103.910 & 0.8363 & 0.48 & & \\
\hline \multirow{4}{*}{$\begin{array}{l}\text { Shannon diversity } \\
\text { index* }\end{array}$} & Year & 0.01034 & 0.00517 & 2 & 3.092 & 0.2360 & 0.80 & \multirow{4}{*}{0.49} & \multirow{4}{*}{0.76} \\
\hline & Shannon diversity index & 1.81810 & 1.81810 & 1 & 83.0277 & 83.0277 & $<0.0001$ & & \\
\hline & Crop stage & 0.03328 & 0.01109 & 3 & 0.5065 & 0.5065 & 0.68 & & \\
\hline & Shannon diversity index $x$ Crop stage & 0.00375 & 0.00125 & 3 & 0.0571 & 0.0571 & 0.98 & & \\
\hline \multirow{4}{*}{$\begin{array}{l}\text { Rao's quadratic } \\
\text { entropy* }\end{array}$} & Year & 0.0025 & 0.0012 & 2 & 2.838 & 0.0100 & 0.99 & \multirow{4}{*}{0.32} & \multirow{4}{*}{0.66} \\
\hline & Rao's quadratic entropy & 6.2766 & 6.2766 & 1 & 111.642 & 51.0293 & $<0.0001$ & & \\
\hline & Crop stage & 1.0473 & 0.3491 & 3 & 96.131 & 2.8382 & 0.04 & & \\
\hline & Rao's quadratic entropy $x$ Crop stage & 0.4093 & 0.1364 & 3 & 100.604 & 1.1093 & 0.35 & & \\
\hline
\end{tabular}

b)

\begin{tabular}{|l|l|c|c|c|}
\hline Response variable & Explanatory variables & Chisq & df & p.value \\
\hline \multirow{4}{*}{ Evenness } & Year & 1.2834 & 2 & 0.53 \\
\cline { 2 - 5 } & Evenness & 6.7798 & 1 & $\mathbf{0 . 0 0 9}$ \\
\cline { 2 - 5 } & Crop stage & 0.7817 & 3 & 0.85 \\
\cline { 2 - 5 } & Evenness $\times$ Crop stage & 3.8198 & 3 & 0.28 \\
\hline
\end{tabular}


Supplementary Table 9: Detailed description of agricultural practices across the six selected plots

\begin{tabular}{|c|c|c|c|c|c|c|c|c|c|c|c|}
\hline Plot & Year & $\begin{array}{l}\text { Crop } \\
\text { (variety) }\end{array}$ & $\begin{array}{l}\text { Preceding } \\
\text { Crop } \\
\text { (harvest } \\
\text { date) }\end{array}$ & Soil preparation & $\begin{array}{l}\text { Sowing } \\
\text { date }\end{array}$ & $\begin{array}{c}\text { Sowing } \\
\text { density } \\
\text { (grains } / \mathrm{m}^{2} \text { ) }\end{array}$ & $\begin{array}{l}\text { Row } \\
\text { spacing } \\
(\mathrm{cm})\end{array}$ & Weed management & Fungicides & Fertilisation & $\begin{array}{l}\text { Harvest } \\
\text { date }\end{array}$ \\
\hline D4 & 2016 & $\begin{array}{l}\text { Winter } \\
\text { barley } \\
\text { (Etincel) }\end{array}$ & $\begin{array}{l}\text { Spring oat } \\
(16 / 07 / 2015)\end{array}$ & $\begin{array}{c}\text { 27/07/2015: Disc harrow } \\
\text { 12/08/2015: Cultivator } \\
\text { 31/08/2015: Disc harrow } \\
\text { 29/09/2015: Spring tine } \\
\text { cultivator } \\
\text { 12/10/2015: Spring tine } \\
\text { cultivator }\end{array}$ & $12 / 10 / 2015$ & 370 & 13.8 & $\begin{array}{l}\text { 23/10/2015: Harrowing } \\
\text { 12/11/2015: Harrowing } \\
\text { 18/03/2016: Harrowing } \\
\text { 28/04/2016: Harrowing }\end{array}$ & $\begin{array}{c}\text { 24/03/2016: Unix max } 0.4 \\
\text { L/ha + Meltop } 5000.45 \\
\text { L/ha } \\
\text { 28/04/2016: Skyway Xpro } \\
0.35 \text { L/ha + Acanto } 0.3 \text { L/ha } \\
\text { + Comet } 0.3 \mathrm{~L} / \text { ha }\end{array}$ & $\begin{array}{l}\text { 18/02/2016: } 150 \mathrm{~kg} / \mathrm{ha} 33.5 \mathrm{~N} \\
14 / 03 / 2016: 210 \mathrm{~kg} / \mathrm{ha} 33.5 \mathrm{~N}\end{array}$ & 29/06/2016 \\
\hline A5 & 2016 & $\begin{array}{l}\text { Winter } \\
\text { wheat } \\
\text { (Nemo) }\end{array}$ & $\begin{array}{l}\text { Oilseed rape } \\
(06 / 07 / 2015)\end{array}$ & $\begin{array}{l}\text { 21/07/2015: Disc harrow } \\
\text { 29/09/2015: Spring tine } \\
\text { cultivator } \\
\text { 20/10/2015: Spring tine } \\
\text { cultivator }\end{array}$ & $26 / 10 / 2015$ & 420 & 13.8 & $\begin{array}{c}\text { 26/10/2015: Harrowing } \\
\text { 06/11/2015: Harrowing } \\
\text { 10/03/2016: Archipel 0.25 kg/ha } \\
\text { + Mix-in 1 L/ha } \\
\text { 22/03/2016: Harrowing }\end{array}$ & $\begin{array}{l}\text { 30/04/2016: Cherokee } 0.6 \\
\text { L/ha } \\
\text { 17/05/2016: Voxan } 0.9 \text { L/ha }\end{array}$ & $\begin{array}{c}\text { 18/02/2016: } 150 \mathrm{~kg} / \mathrm{ha} 33.5 \mathrm{~N} \\
01 / 03 / 2016: 100 \mathrm{~kg} / \mathrm{ha} 26 \mathrm{~N}+32 \mathrm{SO} \\
21 / 03 / 2016: 210 \mathrm{~kg} / \mathrm{ha} 33.5 \mathrm{~N}\end{array}$ & 20/07/2016 \\
\hline D3 & 2017 & $\begin{array}{l}\text { Winter } \\
\text { wheat } \\
\text { (Nemo) }\end{array}$ & $\begin{array}{l}\text { Soybean } \\
(22 / 09 / 2016)\end{array}$ & $\begin{array}{c}\text { 27/09/2016: Disc harrow } \\
\text { 27/09/2016: Cultivator } \\
\text { 28/10/2016: Spring tine } \\
\text { cultivator } \\
\end{array}$ & 29/10/2016 & 370 & 13.8 & $\begin{array}{c}\text { 03/03/2017: Kalenkoa } 0.8 \mathrm{~L} / \mathrm{ha}+ \\
\text { Surf } 20000.1 \mathrm{~L} / \mathrm{ha}\end{array}$ & $\begin{array}{l}\text { 12/05/2017: Voxan 0.8 L/ha } \\
\text { + MgSO4 } 4 \mathrm{~kg} / \mathrm{ha}\end{array}$ & $\begin{array}{c}\text { 20/02/2017: } 150 \mathrm{~kg} / \mathrm{ha} 33.5 \mathrm{~N} \\
\text { 13/03/2017: } 100 \mathrm{~kg} / \mathrm{ha} 26 \mathrm{~N}+32 \mathrm{SO} \\
\text { 27/03/2017: } 120 \mathrm{~kg} / \mathrm{ha} 33.5 \mathrm{~N}\end{array}$ & 07/07/2017 \\
\hline D5 & 2017 & $\begin{array}{l}\text { Winter } \\
\text { wheat } \\
\text { (Nemo) }\end{array}$ & $\begin{array}{l}\text { Soybean } \\
(22 / 09 / 2016)\end{array}$ & $\begin{array}{l}\text { 27/09/2016: Disc harrow } \\
\text { 27/09/2016: Cultivator } \\
\text { 28/10/2016: Spring tine } \\
\text { cultivator }\end{array}$ & 29/10/2016 & 400 & 13.8 & 26/02/2017: Harrowing & $\begin{array}{l}\text { 12/05/2017: Voxan 0.8 L/ha } \\
\text { + MgSO4 } 4 \mathrm{~kg} / \mathrm{ha}\end{array}$ & $\begin{array}{c}\text { 20/02/2017: } 150 \mathrm{~kg} / \mathrm{ha} 33.5 \mathrm{~N} \\
\text { 13/03/2017: } 100 \mathrm{~kg} / \mathrm{ha} 26 \mathrm{~N}+32 \mathrm{SO} \\
\text { 27/03/2017: } 120 \mathrm{~kg} / \mathrm{ha} 33.5 \mathrm{~N}\end{array}$ & 07/07/2017 \\
\hline D13 & 2018 & $\begin{array}{l}\text { Winter } \\
\text { wheat } \\
\text { (Nemo) }\end{array}$ & $\begin{array}{c}\text { Winter } \\
\text { wheat } \\
(07 / 07 / 2017)\end{array}$ & $\begin{array}{c}\text { 20/07/2017: Disc harrow } \\
\text { 10/10/2017: Cultivator } \\
\text { 13/10/2017: Rotary } \\
\text { harrow }\end{array}$ & $16 / 10 / 2017$ & 350 & 13.8 & $\begin{array}{l}\text { 28/07/2017: Barbarian XL } 3 \mathrm{~L} / \mathrm{ha} \\
\text { 22/03/2018: Medzo } 1.2 \mathrm{~L} / \mathrm{ha}+ \\
\text { Gratil } 25 \mathrm{~g} / \mathrm{ha}+\text { Agenda } 1 \mathrm{~L} / \mathrm{ha}\end{array}$ & $\begin{array}{c}\text { 07/05/2018: Cherokee } 1 \\
\text { L/ha + Elatus Plus 0.5 L/ha } \\
\text { 16/05/2018: Amistar } 0.65 \\
\text { L/ha }\end{array}$ & $\begin{array}{c}\text { 22/02/2018: } 150 \mathrm{~kg} / \mathrm{ha} 33.5 \mathrm{~N} \\
\text { 10/04/2018: } 270 \mathrm{~kg} / \mathrm{ha} 33.5 \mathrm{~N} \\
\text { 11/04/2018: } 100 \mathrm{~kg} / \mathrm{ha} 26 \mathrm{~N}+32 \mathrm{SO} 3\end{array}$ & $11 / 07 / 2018$ \\
\hline D15 & 2018 & $\begin{array}{l}\text { Winter } \\
\text { wheat } \\
\text { (Nemo) }\end{array}$ & $\begin{array}{c}\text { Winter } \\
\text { wheat } \\
(07 / 07 / 2017)\end{array}$ & $\begin{array}{c}\text { 20/07/2017: Disc harrow } \\
\text { 10/10/2017: Cultivator } \\
\text { 13/10/2017: Rotary } \\
\text { harrow }\end{array}$ & $17 / 10 / 2017$ & 350 & 13.8 & $\begin{array}{l}\text { 28/07/2017: Barbarian XL } 3 \mathrm{~L} / \mathrm{ha} \\
\text { 22/03/2018: Medzo } 1.2 \mathrm{~L} / \mathrm{ha}+ \\
\text { Gratil } 25 \mathrm{~g} / \mathrm{ha}+\text { Agenda } 1 \mathrm{~L} / \mathrm{ha}\end{array}$ & $\begin{array}{c}\text { 07/05/2018: Cherokee } 1 \\
\text { L/ha + Elatus Plus } 0.5 \text { L/ha } \\
\\
\text { 16/05/2018: Amistar } 0.65 \\
\text { L/ha }\end{array}$ & $\begin{array}{c}\text { 22/02/2018: } 150 \mathrm{~kg} / \mathrm{ha} 33.5 \mathrm{~N} \\
\text { 10/04/2018: } 270 \mathrm{~kg} / \mathrm{ha} 33.5 \mathrm{~N} \\
\text { 11/04/2018: } 100 \mathrm{~kg} / \mathrm{ha} 26 \mathrm{~N}+32 \mathrm{SO} 3\end{array}$ & $11 / 07 / 2018$ \\
\hline
\end{tabular}




\section{Supplementary Figures}

Supplementary Figure 1: Distribution of observed grain yields according to management type and hand weeding across the 3 years, 6 plots and 54 zones
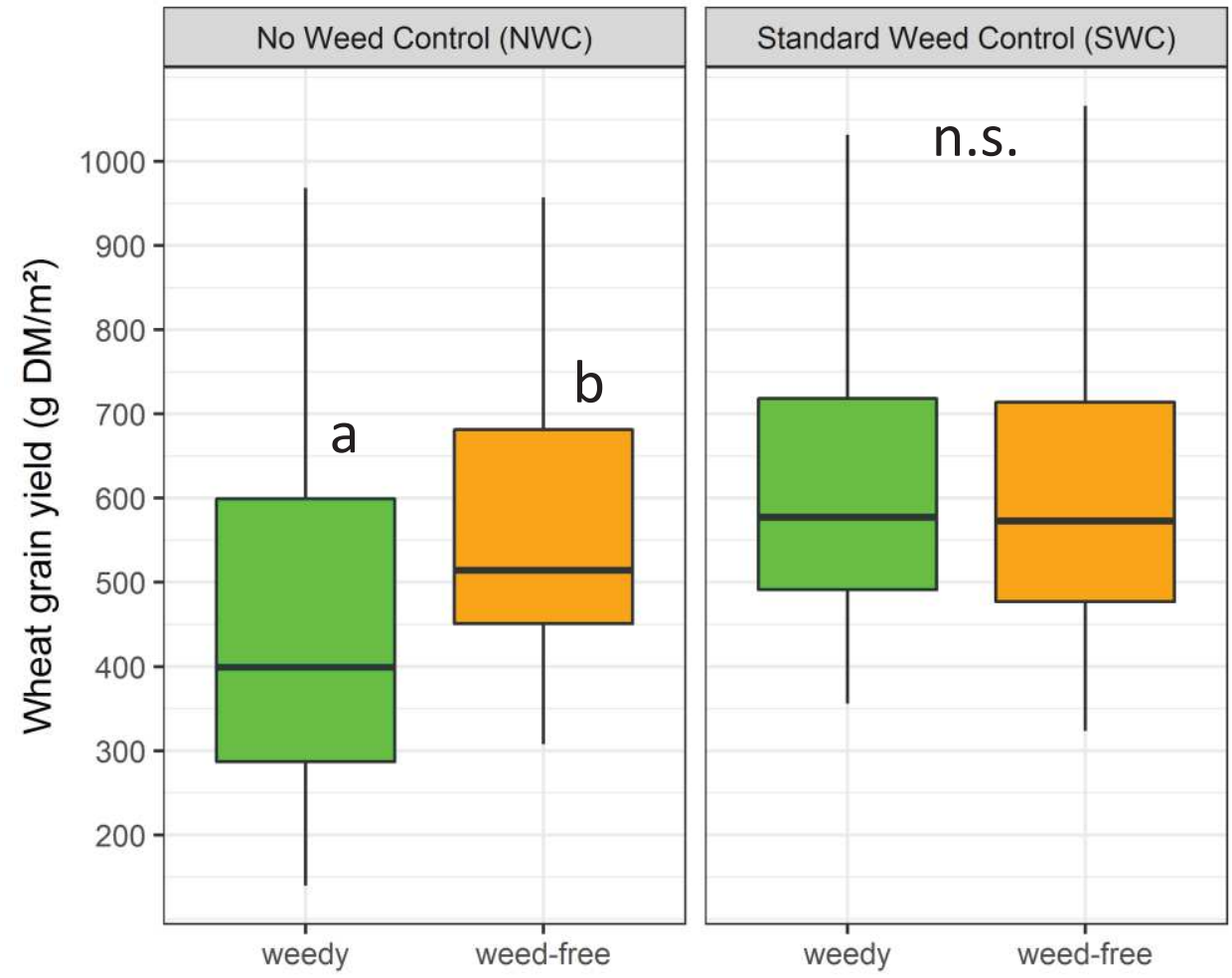
Supplementary figure 2: Principal coordinate analysis on the Bray-Curtis dissimilarity matrix of all 216 weedy quadrats highlighting the six different weed community clusters (named $\mathrm{C} 1$ to C6) obtained by hierarchical classification. Quadrats belonging to the same zone are clustered by spiders. The six different symbols refer to the six plots. Ellipses show the $95 \%$ confidence interval around the estimation of the weed community cluster centroid. Only the eight most abundant species are represented for graphical purposes (VIOAR: Viola arvensis; VERPE: Veronica persica; CENCY: Cyanus segetum; VERHE: Veronica hederifolia; ALOMY: Alopecurus myosuroides; GERDI: Geranium dissectum; GALAP: Galium aparine; STEME: Stellaria media)

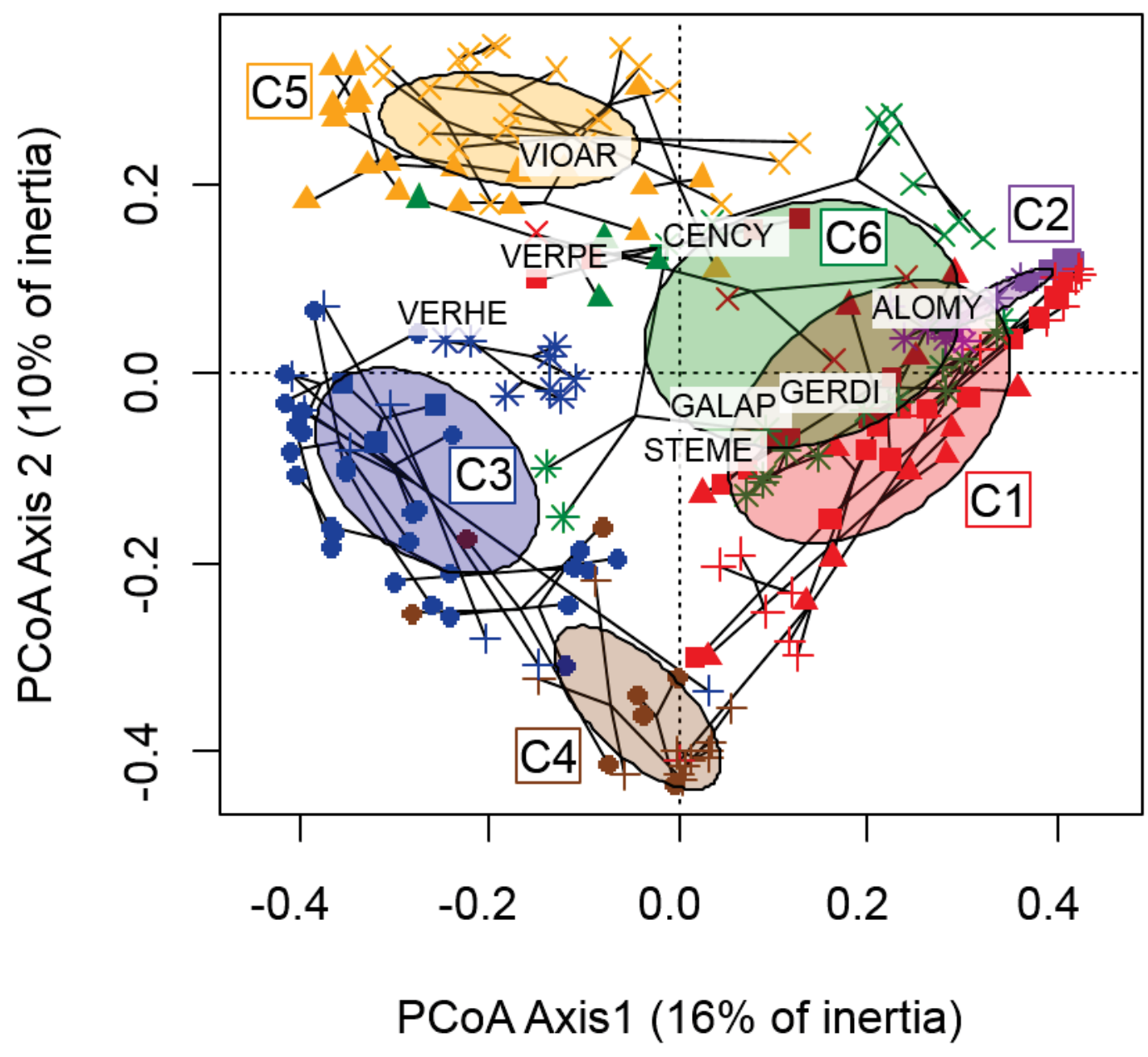


Supplementary figure 3: Distribution of monthly precipitations and average daily temperature over the three cropping seasons of the experiment

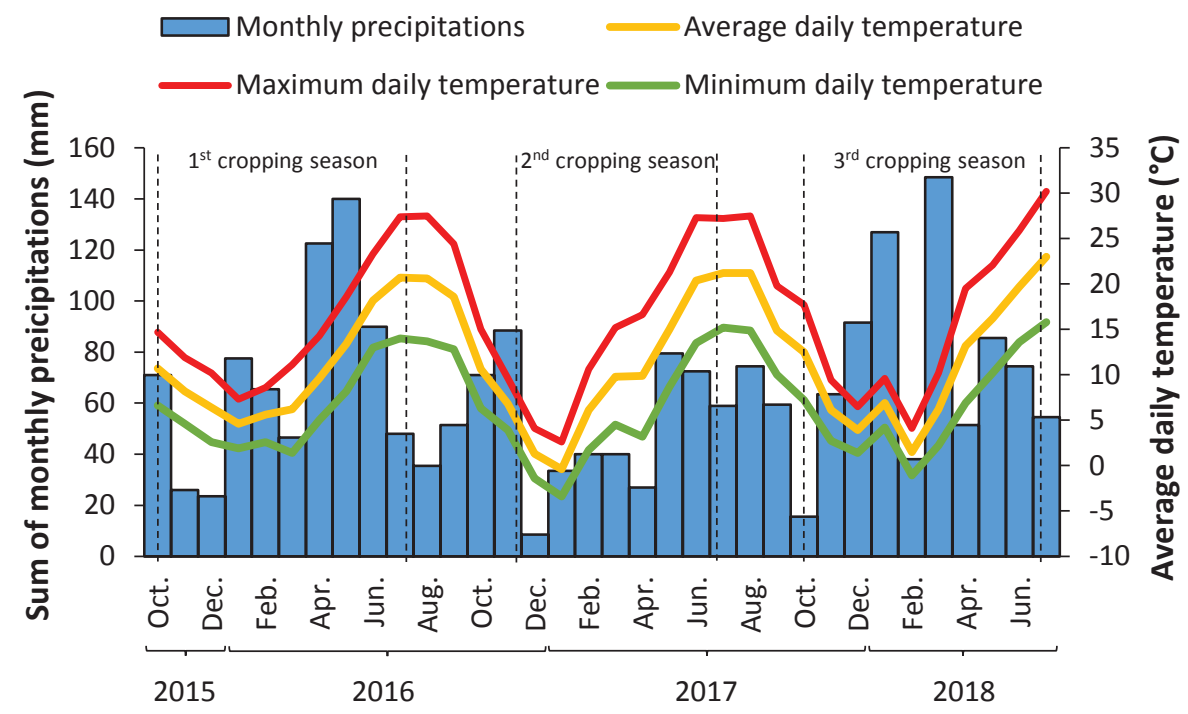


Supplementary figure 4: Diagram of a) the experimental lay-out and b) position of samplings, weeding operations and hand weeding in time

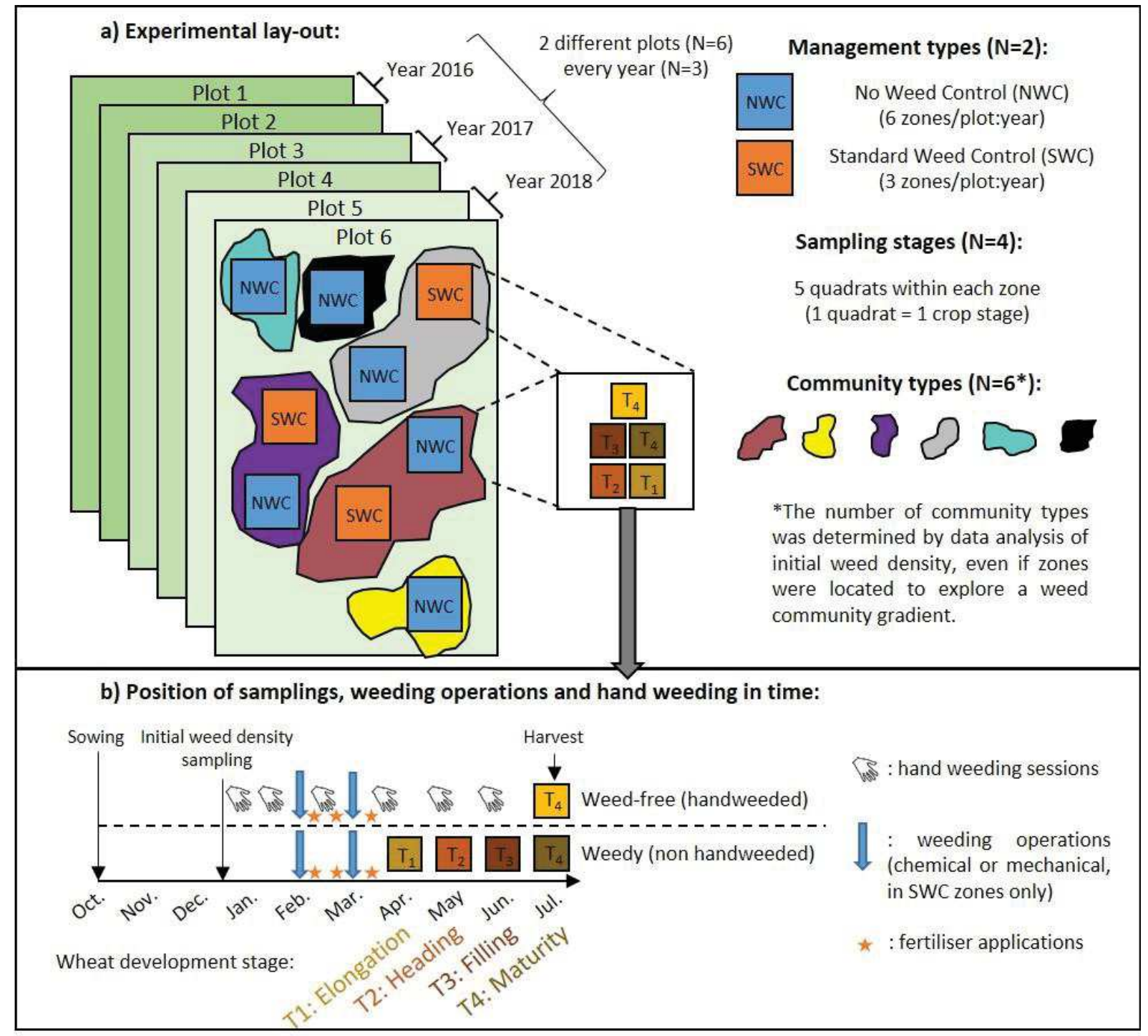

\section{Supplementary References}

1 Guo, Q. \& Rundel, P. W. Measuring dominance and diversity in ecological communities: choosing the right variables. Journal of Vegetation Science 8, 405-408, doi:doi:10.2307/3237331 (1997).

2 Vegan: Community Ecology Package. R package version 1.17-2. https://cran.rproject.org/web/packages/vegan/index.html. Accessed: August 20, 2017 (2010).

3 R: A Language and Environment for Statistical Computing (the R Foundation for Statistical Computing, Vienna, Austria, 2016).

4 Nakagawa, S. \& Schielzeth, H. A general and simple method for obtaining R2 from generalized linear mixed-effects models. Methods in Ecology and Evolution 4, 133-142 (2013). 